\title{
Kortárs egészségfejlesztési programok gyermekek és fiatalok körében a hazai és a nemzetközi szakirodalom tükrében - Szisztematikus áttekintés
}

\author{
Health promotion among children and adolescents by peer education \\ in the Hungarian and international literature - Systematic review
}

Szerzők: Lukács J. Ágnes ${ }^{a} \bowtie$, Mészárosné Darvay Sarolta ${ }^{b}$, Soósné Kiss Zsuzsannac, Füzi Rita ${ }^{d}$, Bihariné Krekó Ilona ${ }^{b}$, Gradvohl Edina ${ }^{a}$, Kolosai Nedda ${ }^{e}$, Falus András ${ }^{f, g}$, Feith Helga Judit ${ }^{a}$

a: Semmelweis Egyetem, Egészségtudományi Kar, Társadalomtudományi Tanszék, Budapest;

b: Eötvös Loránd Tudományegyetem, Tanitó- és Óvóképző Kar, Természettudományi Tanszék,

Budapest; c: Semmelweis Egyetem, Egészségtudományi Kar, Egészségtudományi Klinikai Tanszék, Budapest; d: BFKH II. Kerületi Hivatala, Népegészségügyi Osztály, Budapest; e: Eötvös Loránd Tudományegyetem, Tanító- és Óvóképző Kar, Neveléstudományi Tanszék, Budapest; f: Semmelweis Egyetem, Általános Orvostudományi Kar, Genetikai, Sejt- és Immunbiológiai Intézet, Budapest; g: Eduvital Alapítvány, Budapest

Beküldve: 2017. 12. 03.

doi: 10.24365/ef.v59i1.215

\begin{abstract}
Összefoglaló
Bevezetés: A gyermekek, fiatalok körében megvalósuló kortárs egészségfejlesztő programokra egyre nagyobb az igény, és ezzel együtt növekvő népszerűséget mutatnak mind nemzetközi, mind hazai viszonylatban. Szakirodalom-kutatásunk célja a kortárs egészségfejlesztéssel foglalkozó tanulmányok és programok feltérképezése, valamint bemutatása előre meghatározott szempontrendszer alapján. Tudomásunk szerint jelen tanulmány az eddig közölt legszélesebb szakirodalmi áttekintésen alapuló kritikai elemzés.

Módszertan: Kutatócsoportunk 87, előzetesen kiválasztott, a témához kapcsolódó angol, német és magyar nyelvű tudományos folyóiratban (pl. Health Education Research, Journal of Adolescent Health, Egészségfejlesztés, Lege Artis Medicinae, Orvosi Hetilap, Új Diéta), valamint a PubMed és a ScienceDirect adatbázisokban a „kortársoktatás”, illetve az „egészségfejlesztés” és/vagy „fiatalok/gyermekek" kulcsszavak alapján építette fel a szakirodalmi adatbázist (mindösszesen 101 folyóirat alapján az 1986 és 2017 közötti időszakra kiterjedően). Összesen 173 tanulmányt dolgoztunk fel előre meghatározott szempontok alapján, melyet az elemzés egy pontján kiegészítettünk 21 hazai, tudományos lapban nem publikált, fiatalok, gyermekek körében megvalósuló kortárs egészségfejlesztési program vizsgálatával.

Eredmények: Szakirodalom-kutatásunk tapasztalatait összegezve, a kortársoktatás fogalmi keretei rendkívül széles spektrumot ölelnek fel mind a téma, a kortársoktatók, a célcsoport, a megvalósítás keretei, mind pedig az alkalmazott pedagógiai módszertant illetően. A feldolgozott tanulmányok legnagyobb hiányosságának egyrészt az alkalmazott pedagógiai módszertan pontos leírása, másrészt az egészségfejlesztési programok valid, tudományos hatékonyságmérése bizonyult. A magyar kortárs egészségnevelő kezdeményezések különösen nagy hátrányban vannak a precíz eredményességmérés szempontjából.
\end{abstract}


Következtetések: Az ifjúsági egészségfejlesztési programokban fokozott és kiemelt hangsúlyt szükséges fektetni az alkalmazott pedagógiai módszerek pontos ismertetésére, valamint a program precíz, tudományos hatékonyságmérésére, különösen a hazai programok esetében.

Kulcsszavak: egészségfejlesztés, egészségnevelés, kortárs csoport, fiatalok egészsége, gyermekek egészsége

\begin{abstract}
Summary
Introduction: Peer education programs become more and more expected and popular in the field of health promotion among children and adolescents both at an international and a national level. In our literature review, we explore and describe studies and programs related to health promotion and peer education in different aspects. Based on our best knowledge this critical analysis is the broadest overview on the bibliography, so far.

Methodology: The research group built the database using the keywords "peer education" and "health promotion" or "adolescent/children" in PubMed and ScienceDirect databases and in 87 preselected scientific journals (e.g. Health Education Research, Journal of Adolescent Health, Egészségfejlesztés, Lege Artis Medicinae, Orvosi Hetilap, Új Diéta), in English, German, and Hungarian (101 journals altogether, between 1986 and 2017). 173 studies were analysed by predetermined variables, which data was supplemented with 21 Hungarian, non-published peer educational programs in health promotion among children and adolescents.

Results: Summarizing the results of our literature review, the definitions of the concepts in peer education are still very elusive in terms of the topic, peer educators, target group, program design, and the pedagogical methods. One of the main shortcomings of the analysed studies is the lack of a precise description of the applied pedagogical methods; another one is the lack of a valid, scientific measurement of the efficiency of health promotion programs. Hungarian peer educational initiations show a major hiatus about scientific measurement of the efficiency.

Conclusions: In various health promotion programs for a much more a precise description and emphasized attention of the applied pedagogical methods and a valid, scientific measurement of the efficacy of the programs are required, especially in the case of the Hungarian practice.

Keywords: health promotion, health education, peer group, adolescent health, child health
\end{abstract}

\section{BEVEZETÉS}

A gyermekek, fiatalok körében megvalósuló kortárs egészségfejlesztő programok egyre nagyobb népszerűségnek örvendenek nemzetközi és hazai viszonylatban egyaránt. Miután ezeket a programokat a kortársoktatás szellemisége hatja át, sokkal inkább képesek megszólítani a fiatal generációkat, szemben a hagyományos, frontális oktatásra épülő programokkal. Ezek a kezdeményezések rendkívül sokszínúek mind a kortársoktatók meghatározását, szerepét, mind a kortársoktatás keretein belül alkalmazott módszereket illetően, de a célcsoport vonatkozásában is. A széleskörű alkalmazás ellenére a kortársoktatás súlyos definíciós hiátussal küzd. ${ }^{1,2}$ Tanulmányunkban nem célunk a kortársoktatás fogalmának, történeti vonatkozásainak, valamint elméleti hátterének vizsgálata, a már publikált egészségfejlesztési programok elemzésére koncentrálunk. Hiánypótló tanulmányunkban hazai és nemzetközi, a fiatalok és gyermekek számára kidolgozott kortárs egészségfejlesztési programokat mutatunk be szisztematikus szakirodalom-kutatásunk eredményei alapján. A kiválasztott tanulmányok és programok feldolgozását előre meghatározott szempontrendszer alapján végeztük, elsősorban a kortárs egészségfejlesztési projektek megvalósulásának kereteire fókuszálva.

Szakirodalmi kutatásunk motivációját saját egészségfejlesztési kezdeményezésünk, a Magyar Tudományos Akadémia Tantárgy-pedagógiai Kutatási Program keretein belül megvalósuló TANTUdSZ (Tanulj, tanítsd, tudd!) Ifjúsági Egészségnevelési Program megalapozása adta. ${ }^{3}$ Célunk az volt, hogy áttekintsük a hazai és nemzetközi, fiatalok, gyermekek egészségfejlesztésével 
foglalkozó kortárs programok tapasztalatait és bevált megvalósítását.

Mielőtt kutatásunkat bemutatjuk, reflektálnunk kell az „egészségnevelés” vs. „egészségfejlesztés” kifejezésekre. A két fogalom egymáshoz való viszonyáról a mai napig nincs konszenzus a nemzetközi és a hazai szakirodalomban., ${ }^{4,5}$ Szakirodalmi kutatásunkban és tanulmányunkban egyaránt az „egészségfejlesztés" kifejezést használjuk, értve alatta a nem csupán tudásátadásra, egyéni készségek fejlesztésére irányuló programokat, hanem az egészségmagatartásra, attitűdformálásra, az egészséget támogató környezet kialakítására fókuszáló komplexebb kezdeményezéseket.

\section{MÓDSZERTAN}

Kutatócsoportunk 2016 őszétől 2017 őszéig 87, előzetesen kiválasztott, a témához kapcsolódó, főként egészségfejlesztési, egészségtudományi és pedagó- giai, angol, német és magyar nyelvü tudományos folyóiratban (pl. Health Education Research, Journal of Adolescent Health, Egészségfejlesztés, Lege Artis Medicinae, Orvosi Hetilap, új Diéta), valamint a PubMed, a ScienceDirect adatbázisokban a "kortársoktatás”, illetve az „egészségfejlesztés” és/vagy "fiatalok/gyermekek” kulcsszavak alapján építette fel a szakirodalmi adatbázist. Adatbázisunkba kifejezetten azokat az egészségfejlesztéssel foglalkozó, kortársoktatást alkalmazó programokat feldolgozó tanulmányokat emeltük be, amelyek célcsoportját a gyermekek, fiatalok (3-25 éves korosztály) jelentették. Elemzésünkből kizártuk azokat a tanulmányokat, amelyek nem feleltek meg a fenti három kritériumnak, valamint a review cikkeket sem dolgoztuk fel [1. ábra].

Összesen 101 folyóirat tanulmányai közül válogattunk, amelyek 60\%-a egészségtudományi, egynegyede egészségfejlesztési, 13 folyóirat pedig pedagógiai, pszichológiai, és társadalomtudományi profilú.

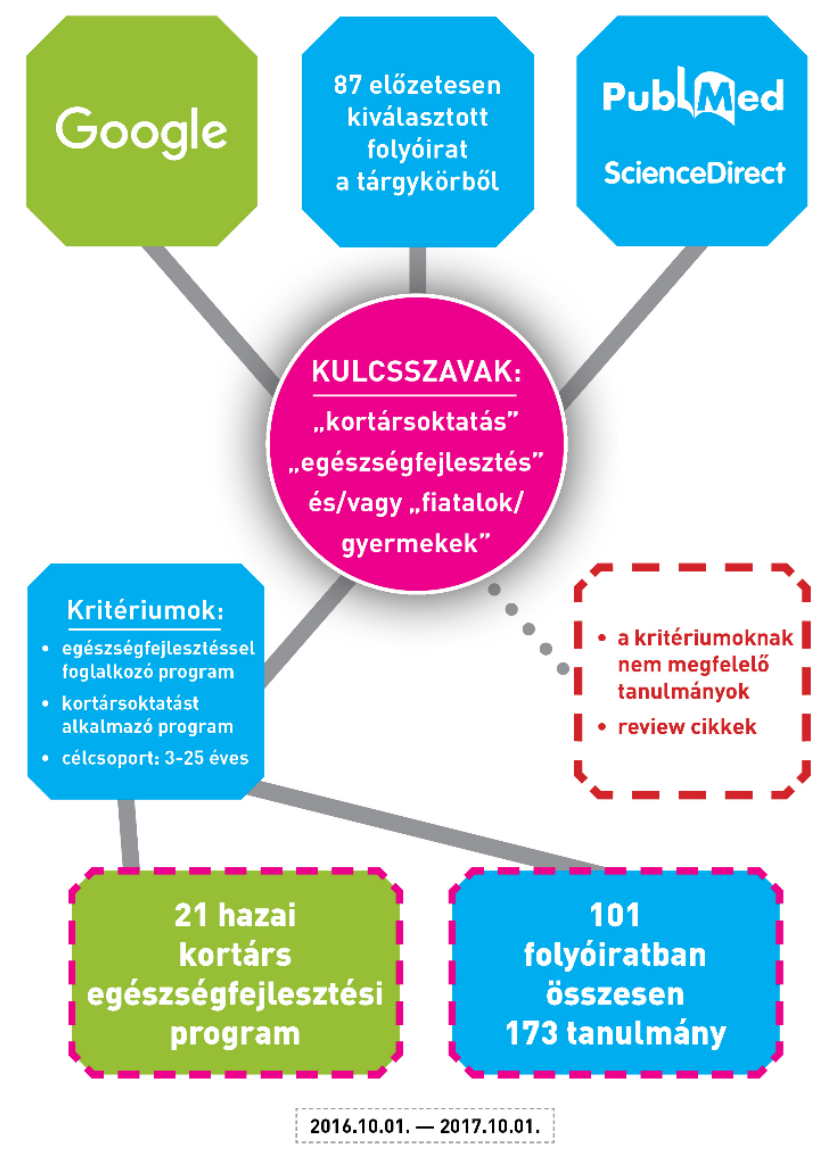

Forrás: saját szerkesztés 
Kutatásunk kizárólag a digitalizált publikációkra terjedt ki, így a korábban, nyomtatott formában megjelent szakirodalmat nem vizsgáltuk. Összesen 173 tanulmányt [1. táblázat] dolgoztunk fel, előre meghatározott elemzési szempontok alapján.

Az elemzés során vizsgáltuk:

- a kortárs egészségfejlesztési program tematikáját;

- a kortársoktatók és a célcsoport életkorát;

- a megvalósítás évét és helyét (ország);

- a kivitelezés formális-informális voltát (volt-e intézményesült felkészítés a kortársoktatók számára);

- a megvalósítás kereteit (iskolai, vagy egyéb);

- a program hosszát, rendszerességét (egy alkalommal, hosszabb ideig és/vagy ismétlődő jelleggel);

- az alkalmazott speciális pedagógiai módszertant;

- a hatékonyság mérésének jellemzőit (módszer, indikátorok).

Az említett főbb dimenziók leírása mellett kíváncsiak voltunk egyrészt, hogy kirajzolódnak-e időben bizonyos tendenciák, másrészt, hogy az egyes vizsgálati szempontok alapján kimutathatók-e eltérések. Adatbázisunkat SPSS statisztikai programmal elemeztük, a leíró statisztikák mellett kereszttáblaelemzést és $C^{2}{ }^{2}$-próbát alkalmaztunk.

Szakirodalmi áttekintésünkben mindenképpen szerettük volna megismerni a hazai gyakorlatokat, ugyanakkor mindössze hét olyan publikációt találtunk, amely megfelelt a kritériumainknak (két nemzetközi, öt hazai folyóiratban publikált tanulmány). Ezeket kiegészítettük 21 hazai, gyermekek, fiatalok számára kidolgozott, kortárs egészségfejlesztéssel foglalkozó kezdeményezés tapasztalataival. Ezekre a kezdeményezésekre a Google böngészőben kerestünk rá a „kortársoktatás”, „kortársképzés”, „kortársprogramok” kulcsszavak segítségével, és az így talált, tudományos lapban nem publikált programok interneten elérhető leírását dolgoztuk fel.

\section{EREDMÉNYEK}

A tudományos folyóiratokban megjelent, javarészt nemzetközi publikációk elemzése után a hazai kezdeményezéseket jellemezzük a nemzetközi kortárs egészségfejlesztési programok tükrében.

A gyermekek, fiatalok körében végzett kortárs egészségneveléssel foglalkozó publikációk száma az utóbbi két évtizedben jelentősen megnövekedett [2. ábra]. A megadott kulcsszavak alapján, a digitalizáltan megjelent forrásokból felépített adatbázis legkorábbi tanulmánya 1986-ban jelent meg, ugyanakkor ismeretes, hogy a kortársoktatás a '70-es években már nagy népszerüségnek örvendett az egészségnevelés területén. ${ }^{6,7}$ A vizsgálatba bevont tanulmányok által feldolgozott kortárs egészségfejlesztési programok többsége a '90-es évek közepe és 2010 között valósult meg.

2. ábra: Gyermekek-fiatalok körében megvalósuló kortárs egészségfejlesztési programokat feldolgozó, vizsgálatba bevont publikációk ( $n=173)$

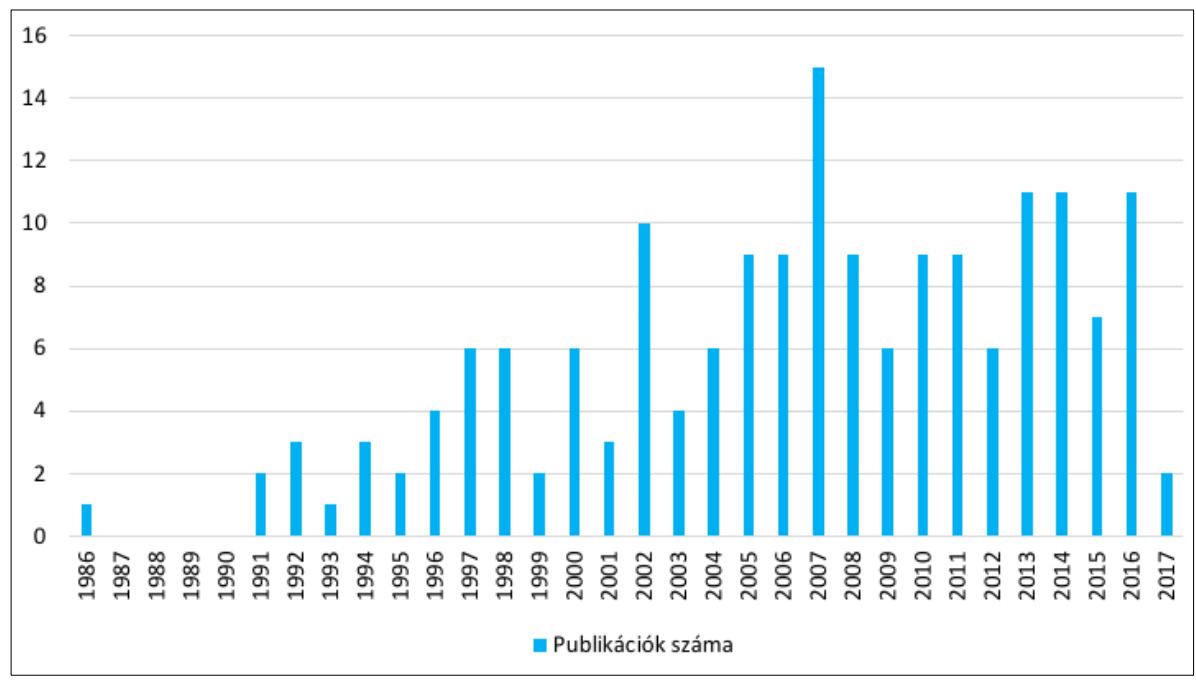

Forrás: saját szerkesztés 
A projektek több mint fele szexuális neveléssel foglalkozott, ezen belül is a legtöbb a HIV-prevencióra koncentrált. A táplálkozásra fókuszáló programok szintén népszerűek (13\%), ahogy a káros szenvedélyekkel (drogprevenció, dohányzás) dolgozó kezdeményezések is (11\%). [3. ábra]

A vizsgálatunkba bevont tanulmányok 40\%-a északamerikai (ezen belül is jellemzően az Egyesült Államokból származó) projekteket dolgozott fel, 21\% pedig európai, leginkább Egyesült Királyságbeli kortárs egészségnevelő projektekről írt. Mindezek mellett számottevő arányban találhatók afrikai (18\%), valamint ázsiai (17\%) kortárs egészségfejlesztő kezdeményezések a szakirodalmi adatbázisban.
Vizsgáltuk azt is, hogy a gyermekek, fiatalok körében végzett kortárs egészségfejlesztő programok pontosan milyen életkori csoportokat céloztak meg. Összesen 109 program esetében tudtuk meg a kortársoktatók korát, és 142 olyan publikált kezdeményezés volt, amely pontosan leírta a célcsoport életkorát. A 15-18 éves korcsoportból került ki a kortársoktatók csaknem kétharmada, de az egyes programok nagy arányban (közel 36\%) dolgoznak 19 éves vagy idősebb kortársoktatókkal. [4. ábra] A kortárs egészségfejlesztési kezdeményezések 17\%-ában egyszerre több korcsoportból verbuválnak kortársoktatókat, legnagyobb részük (11\%) középiskolásokkal és egyetemista kortársoktatókkal dolgozik.

3. ábra: Gyermekek-fiatalok körében végzett kortárs egészségfejlesztési programok témái $(n=173)$

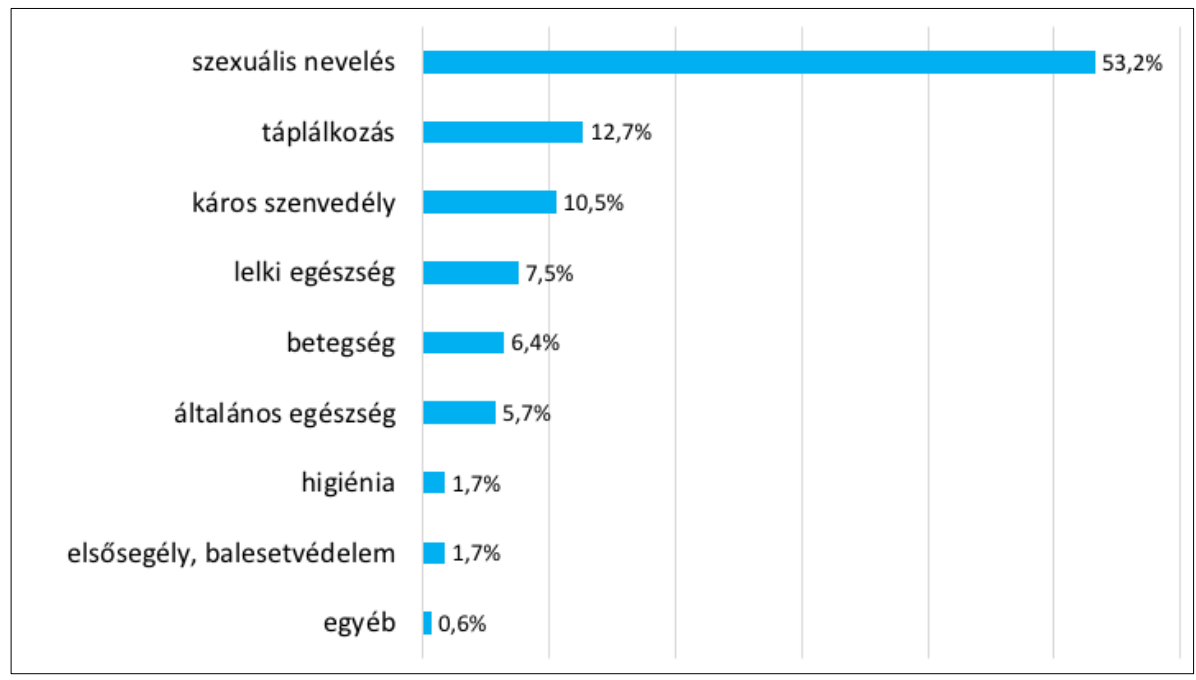

Forrás: saját szerkesztés

A 15-18 éves korcsoport jelentette a kortárs egészségfejlesztő programok fő célcsoportját, de a 11-14 éves korosztály számára is nagy arányban tartottak foglalkozásokat. Érdekességként tapasztaltuk, hogy 13,4\%-ban előfordultak ennél fiatalabb korosztály, 3-10 évesek számára szervezett programok is. [5. ábra] Az egészségfejlesztési kezdeményezések harmada vegyes életkori csoportokra koncentrál, 12\%-ukat 11-18 évesek számára fejlesztették ki, másik 12\%-uk a középiskolás és idősebb fiatalokkal dolgozik. Az általunk vizsgált 142 publikált program közül egyetlen egy olyat sem találtunk, amely összevonná a gyermekeket a kisiskolás korosztálytól egészen az egyetemistákig.

A kortársoktatók és a célcsoport életkori csoportja az esetek háromnegyedében átfedést mutatott, illetve megegyezett, a programok 19\%-ában pedig a kortársoktatók átlagosan 4-5 évvel voltak idősebbek a célcsoportnál. Adataink alapján a kisiskolások és felső tagozatosok esetében jellemzőbb az idősebb kortársoktatók részvétele $\left(\mathrm{Chi}^{2}\right.$-teszt $\left.\mathrm{p}<0,001\right)$. A kortárs egészségfejlesztés témája differenciálja a célcsoportot is: a nemi neveléssel kapcsolatos programok $74 \%$-a, a káros szenvedélyek prevenciójával foglalkozó kezdeményezések 72\%-a középiskolásokat célozta meg (Chi ${ }^{2}$-teszt $\left.\mathrm{p}=0,005\right)$. A higiénével, valamint az balesetmegelőzéssel, elsősegélynyújtással foglalkozó programok kétharmada a 3-10 éves korosztály körében szerveződött (Chi ${ }^{2}$-teszt $p<0,001)$. 
4. ábra: Az egészségfejlesztési programokban részt vevő kortársoktatók korcsoport szerint ( $\left.n=109^{*}\right)$

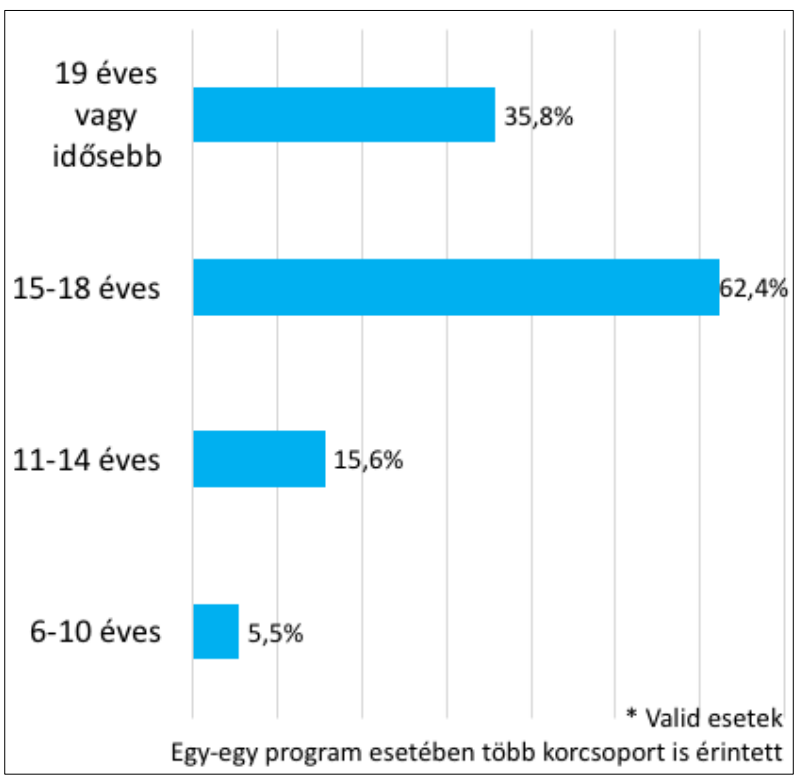

Forrás: saját szerkesztés

5. ábra: A kortárs egészségfejlesztési programok célcsoportjai életkor szerint $(n=142 *)$

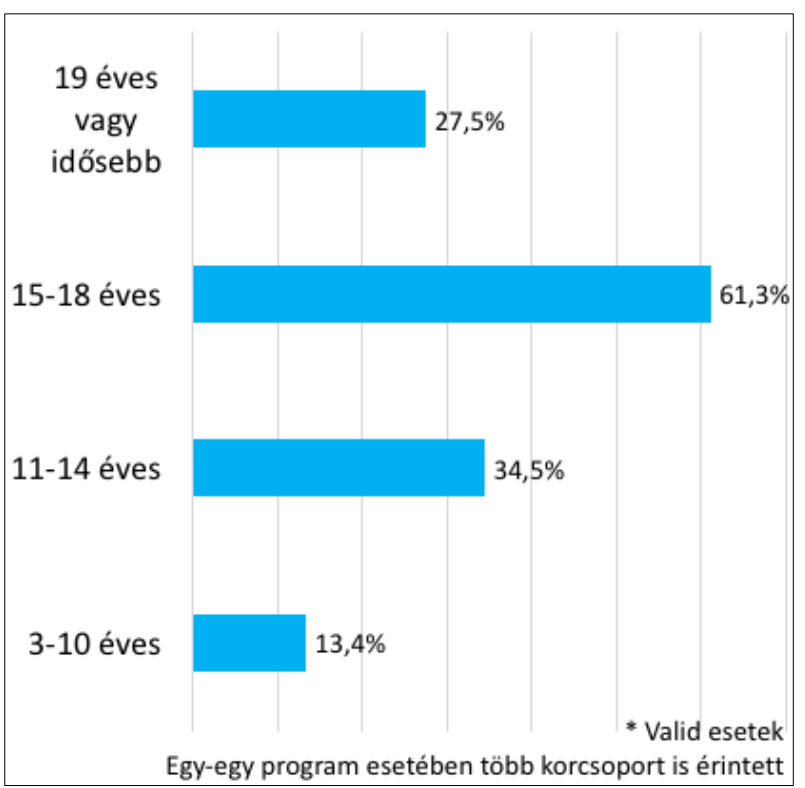

Forrás: saját szerkesztés

Ahogy a módszertani fejezetben kifejtettük, kutatásunk során mindenképpen szerettük volna megismerni a hazai, gyermekek, fiatalok körében megvalósuló kortárs egészségfejlesztési gyakorlatokat, ugyanakkor nagyon kevés tudományos publikációt találtunk a témában. Elemzésünket ezért kiegészítettük 21, tudományos lapban nem publikált magyar kezdeményezés vizsgálatával. A magyar kortárs egészségfejlesztő programok - gyűjtésünk alapján - a '90-es évektől kezdtek népszerűvé válni. A hazai projektek tematikájában nagyobb hangsúlylyal jelennek meg a mentális egészséggel (személyiségfejlesztés, közösségfejlesztés, tanácsadás), valamint a szerhasználat és dohányzás megelőzésére épülő kezdeményezések a nemzetközi példákhoz viszonyítva (Chi²-teszt $p<0,001)$. A hazai kortárs egészségfejlesztő programok többségében az egyetemista korosztályból kerülnek ki a kortársoktatók (Chi²-teszt $p<0,001)$. Ugyanígy, a célcsoport esetében is felülreprezentált módon jelennek meg a 18 évnél idősebb fiatalok a nemzetközi programokhoz képest (Chi ${ }^{2}$-teszt $p=0,002$ ). Talán ezzel függ össze, hogy a magyar kortárs egészségnevelő projektek sokkal kevésbé kötődnek oktatási intézményekhez, túlnyomó többségük iskolán kívüli tevékenység keretei között valósul meg (Chi²-teszt $p<0,001)$. Eredményeink alapján a hazai kezdeményezések között magasabb arányban jelennek meg a rendszeres, ismétlődő kortárs egészségfejlesztő programok a nemzetközi gyakorlathoz képest (Chi²-teszt $p=0,024)$. Ezzel együtt, a magyar projektek alig több mint felében mérik a kortársoktatás eredményességét, amíg ez az arány a külföldi programok esetében 90\% feletti (Chi²-teszt $p<0,001)$.

\section{MEGBESZÉLÉS}

A gyermekek, fiatalok körében végzett kortárs egészségfejlesztő programokra egyre nagyobb az igény, és ezzel együtt növekvő népszerűséget mutatnak mind nemzetközi, mind hazai viszonylatban. A magyar társadalom jelenlegi egészségi állapota és távlati kilátásai minden felelősen gondolkodó számára kötelező feladatokat jelölnek ki. Ebben az egészségtudatosságra való évtizedes stratégiával megalapozott egészségnevelés kulcsszerepet játszik. Megfelelő eredmény elérése csak a hazai és nemzetközi tapasztalatok ismeretében lehetséges. Szisztematikus és a lehető legnagyobb teljességre törekvő szakirodalmi kutatásunk alapján elmondható, hogy ezek a programok rendkívül széles horizonton mozognak mind a tematikát, mind a kortársoktatók és a célcsoport életkorát illetően. Az egyes projektek megvalósításának keretei ugyancsak sokszínúséget mutatnak akár a programok időtartamában, helyszínében, de a kortársoktatók felkészítésében is. Lényeges hiányt jelent a kortársoktatással foglalkozó tanulmányok esetében 
az alkalmazott pedagógiai módszertan pontos leírása. Ez az a probléma, amelyre a szakirodalom a kortársoktatás „fekete dobozaként” hivatkozik, hiszen anélkül, hogy tudnánk, pontosan milyen pedagógiai módszerek kerülnek alkalmazásra egyegy kortársoktatási foglalkozás keretein belül, az egyes programok eredményességének értelmezése sem lehetséges. ${ }^{14}$ Ugyan a kortársoktatás eredményességét a legtöbb program méri, de a hatásvizsgálat pontos módszertani keretei (elő- és utómérés, kontrollcsoport) nem minden esetben tisztázottak, ahogy ezt több nemzetközi összefoglaló cikk is kiemeli. ${ }^{15,16}$

A magyar kortárs egészségnevelő kezdeményezések különösen nagy hátrányban vannak a precíz eredményességmérés szempontjából. ${ }^{17}$ Irodalomkutatásunk arra is rámutatott, hogy a hazai, iskolai keretek között megvalósuló, egyszersmind publikált egészségnevelési programok száma sajnálatosan messze elmarad más országok programjainak számától és hatékonyságának méréstől is. Ez talán a koncepciózusan felépített és a hatékonyságot tudományosan mérő programok alacsony számával magyarázható.

Szakirodalmi kutatásunk tapasztalatait összegezve a kortársoktatás fogalmi keretei rendkívül széles spektrumot ölelnek fel mind a téma, mind a kortársoktatók, a célcsoport, a megvalósítás keretei, mind pedig az alkalmazott pedagógiai módszertan vonatkozásában. A feldolgozott tanulmányok túlnyomó többsége egyrészt az alkalmazott pedagógiai módszertan pontos leírásával, másrészt az egészségfejlesztési programok valid, tudományos hatékonyságmérésével maradnak adósak.

\section{Anyagi támogatás}

A kutatás a Magyar Tudományos Akadémia támogatásával, a Tantárgy-pedagógiai Kutatási Program keretein belül valósult meg. ${ }^{18}$

\section{Köszönetnyilvánítás}

Szeretnénk köszönetet mondani kutatócsoportunk azon tagjainak, akik a tanulmány alapját képező szakirodalom-kutatásban részt vettek: Ábrám Boróka, Berta Kata, Bihariné dr. Krekó Ilona, Deák Alexandra, Dr. Feith Helga Judit, Dr. Füzi Rita, Lovas Krisztina, Lukács J. Ágnes, Mészárosné Dr. habil. Darvay Sarolta, Soósné Dr. habil. Kiss Zsuzsanna, Szőke Andrea.

\section{HIVATKOZÁSOK}

${ }^{1}$ Milburn K. A Critical Review of Peer Education with Young People with Special Reference to Sexual Health. Health Educ Res. 1995;10(4):407-420.

${ }^{2}$ Shiner M. Defining Peer Education. J Adolesc. 1999;22:555-566. doi:10.1006/jado.1999.0248

${ }^{3}$ Feith HJ, Melicher D, Falus A. Utószó helyett a TANTUdSZ programról. In: Falus A, Melicher D. (szerk.) Sokszínű egészségtudatosság, Értsd, csináld, szeresd! SpringMed Kiadó, Budapest, 2015. pp. 293-297.

${ }^{4}$ Kósa K. Van-e hazai közmegegyezés arról, hogy mi az egészségfejlesztés? Népegészségügy. 2010;88(1):3-10.

${ }^{5}$ Hills M, Carroll S. Health Promotion, Health Education and the Public Health. In Oxford Textbook of Public Health (5.ed.), Detels R, Beaglehole R, Lansang MA, et al. (eds.) Oxford University Press, Oxford, 2009. pp. 17-69.

${ }^{6}$ Sloane BC, Zimmer CG. The Power of Peer Health Education. J. Am. Coll. Health. 1993;41(6):241-245. doi:10.1080/07448481.1993.9936334

7 Turner G, Shepherd J. A Method in Search of a Theory: Peer Education and Health Promotion. Health Educ Res. 1999;14(2):235-247.

${ }^{8}$ Sheehan K, DiCara JA, LeBailly S. et al. Adapting the Gang Model: Peer Mentoring for Violence Prevention. Pediatrics. 1999;104(1 Pt 1):50-4. doi:10.1542/peds.104.1.50

${ }^{9}$ Ebreo A, Feist-Price S, Siewe Y. et al. Effects of Peer Education on the Peer Educators in a School-Based HIV Prevention Program: Where Should Peer Education Research Go From Here? Health Educ. Behav. 2002;29(4):411-423. doi:10.1177/109019810202900402

10 Pbert L, Fletcher KE, Flint AJ. et al. Smoking Prevention and Cessation Intervention Delivery by Pediatric Providers, as Assessed with Patient Exit Interviews. Pediatrics. 2006;118(3):e810-24. doi:10.1542/peds.2005-2869 
${ }^{11}$ Stock S, Miranda C, Evans S. et al. Healthy Buddies: A Novel, Peer-Led Health Promotion Program for the Prevention of Obesity and Eating Disorders in Children in Elementary School. Pediatrics. 2007;120(4):e1059-68.

doi:10.1542/peds.2006-3003

${ }^{12}$ Al-sheyab N, Gallagher R, Crips J. et al. Peer-led Education for Adolescents with Asthma in Jordan: A Cluster-Randomized Controlled Trial. Pediatrics. 2012;129(1):e106-12. doi:10.1542/peds.2011-0346

${ }^{13}$ Sharif Ishak SI, Chin YS, Mohd Taib MN. et al. School-based Intervention to Prevent Overweight and Disordered Eating in Secondary School Malaysian Adolescents: A Study Protocol. BMC Public Health. 2016;16(1):1101.

${ }^{14}$ Southgate E, Aggleton P. Peer Education: From Enduring Problematics to Pedagogical Potential. Health Educ J. 2016;76(1):1-12. doi:10.1177/0017896916641459

${ }^{15}$ Mellanby AR, Rees JB, Tripp JH. Peer-led and Adult-led School Health Education: a Critical Review of Available Comparative Research. Health Educ Res. 2000;15(5):533-545.

${ }^{16}$ Tolli MV. Effectiveness of Peer Education Interventions for HIV Prevention, Adolescent Pregnancy Prevention and Sexual Health Promotion for Young People: A Systematic Review of European Studies. Health Educ Res. 2012;27(5):904913. doi:10.1093/her/cys055

17 Tóth G, Formanek-Balku E. Támpontok az egészségfejlesztéssel kapcsolatos kutatásokhoz. Következtetések a 2015-ös Egészségfejlesztés folyóiratban ismertetett kutatások áttekintése alapján. Egészségfejlesztés. 2016;57(4):47-54.

${ }^{18}$ Magyar Tudományos Akadémia Tantárgy-pedagógiai Kutatási Program http://mta.hu/tantargy-pedagogiai-kutatasiprogram (Elérve: 2018.02.06.) 


\section{MELLÉKLET}

1. táblázat: A kutatás által feldolgozott tanulmányok és programok

\begin{tabular}{|c|c|c|c|}
\hline & Citáció & Téma & Kontinens \\
\hline 1 & $\begin{array}{l}\text { Perry CL, Klepp KI, Halper A, et al. A process evaluation study of peer leaders in health } \\
\text { education. J Sch Health. 1986;56(2):62-7. }\end{array}$ & $\begin{array}{l}\text { káros szenve- } \\
\text { dély }\end{array}$ & Észak-Amerika \\
\hline 2 & $\begin{array}{l}\text { Wiist WH, Snider G. Peer education in friendship cliques: prevention of adolescent smo- } \\
\text { king. Health Educ Res. 1991;6(1):101-108. }\end{array}$ & $\begin{array}{l}\text { káros szenve- } \\
\text { dély }\end{array}$ & Észak-Amerika \\
\hline 3 & $\begin{array}{l}\text { Slap GB, Plotkin SL, Khalid, N et al. A human immunodeficiency virus peer education } \\
\text { program for adolescent females. J Adolesc Helath. 1991;12(6):434-442. }\end{array}$ & $\begin{array}{l}\text { szexuális ne- } \\
\text { velés }\end{array}$ & Észak-Amerika \\
\hline 4 & $\begin{array}{l}\text { Fork HE, Wagner RF, Wagner KD. The Texas peer education sun awareness project for } \\
\text { children: primary prevention of malignant melanoma and nonmelanocytic skin cancers. } \\
\text { Cutis. 1992;50(5):363-364. }\end{array}$ & betegség & Észak-Amerika \\
\hline 5 & Aids Peer Education Exchange. Health Educ Q. 1992;19(4):425. & $\begin{array}{l}\text { szexuális ne- } \\
\text { velés }\end{array}$ & Észak-Amerika \\
\hline 6 & $\begin{array}{l}\text { The Initiation of HIV/AIDS Peer Education in a Rural College Setting. Health Educ Q. } \\
\qquad 1992 ; 19(4): 426-427 .\end{array}$ & $\begin{array}{l}\text { szexuális ne- } \\
\text { velés }\end{array}$ & Észak-Amerika \\
\hline 7 & $\begin{array}{l}\text { Florida teenagers learn about AIDS, teach others. Netw Res Triangle Park N C. } \\
\qquad 1993 ; 13(4): 12-5 .\end{array}$ & $\begin{array}{l}\text { szexuális ne- } \\
\text { velés }\end{array}$ & Észak-Amerika \\
\hline 8 & $\begin{array}{l}\text { Richie ND, Getty A. Did an AIDS peer education program change first-year college stu- } \\
\text { dents' behaviors? J Am Coll Health. 1994;42(4):163-5. }\end{array}$ & $\begin{array}{l}\text { szexuális ne- } \\
\text { velés }\end{array}$ & Észak-Amerika \\
\hline 9 & $\begin{array}{l}\text { Klein NA, et al. Understanding volunteer peer health educators' motivations: applying } \\
\text { social learning theory. J Am Coll Health. 1994;43(3):126-30. }\end{array}$ & $\begin{array}{l}\text { általános } \\
\text { egészség }\end{array}$ & Észak-Amerika \\
\hline 10 & $\begin{array}{l}\text { Giuliano JD. A peer education program to promote the use of conflict resolution skills } \\
\text { among at-risk school age males. Public Health Rep. 1994;109(2):158-161. }\end{array}$ & lelki egészség & Észak-Amerika \\
\hline 11 & $\begin{array}{l}\text { Matsumoto S. Sex education and sexual behaviour of adolescents in Japan. Ann Acad } \\
\qquad \text { Med Singapore. 1995;24(5):696-699. }\end{array}$ & $\begin{array}{l}\text { szexuális ne- } \\
\text { velés }\end{array}$ & Ázsia \\
\hline 12 & $\begin{array}{l}\text { Reding DJ, Fischer V, Gunderson P, et al. Skin cancer prevention: a peer education mo- } \\
\qquad \text { del. Wis Med J. } 1995 ; 94(2): 77-81 .\end{array}$ & betegség & Észak-Amerika \\
\hline 13 & $\begin{array}{l}\text { Dadian M. Peer education helps Jamaican youth choose less risky behaviors. AIDSlink. } \\
\qquad 1996 ;(41): 7 .\end{array}$ & $\begin{array}{l}\text { szexuális ne- } \\
\text { velés }\end{array}$ & Észak-Amerika \\
\hline 14 & $\begin{array}{l}\text { Wiist WH, Jackson RH, Jackson KW. Peer and community leader education to prevent } \\
\text { youth violence. Am J Prev Med. 1996;12(5 Suppl):56-64. }\end{array}$ & lelki egészség & Észak-Amerika \\
\hline 15 & $\begin{array}{l}\text { McAleavy G, McCrystal P, Kelly G. Peer education: a strategy for improving health edu- } \\
\text { cation in disadvantaged areas in Belfast. Public Health. 1996;110(1):31-36. }\end{array}$ & $\begin{array}{l}\text { káros szenve- } \\
\text { dély }\end{array}$ & Európa \\
\hline 16 & $\begin{array}{l}\text { O'hara P, Messick BJ, Fichtner RR, et al. A peer-led AIDS prevention program for stu- } \\
\text { dents in an alternative school. J Sch Health. 1996;66(5):176-182. }\end{array}$ & $\begin{array}{l}\text { szexuális ne- } \\
\text { velés }\end{array}$ & Észak-Amerika \\
\hline 17 & $\begin{array}{l}\text { Kauffman C, Hue L. Sustaining youth peer HIV / STD prevention education. AIDS STD He- } \\
\text { alth Promot Exch. 1997;(3):3-7. }\end{array}$ & $\begin{array}{l}\text { szexuális ne- } \\
\text { velés }\end{array}$ & Észak-Amerika \\
\hline 18 & $\begin{array}{l}\text { Maurer F. A peer education model for teaching breast self-examination to undergra- } \\
\text { duate college women. Cancer Nurs. 1997;20(1):49-61. }\end{array}$ & betegség & Észak-Amerika \\
\hline
\end{tabular}




\begin{tabular}{|c|c|c|c|}
\hline 19 & $\begin{array}{l}\text { Shaw RA, Rosati MJ, Salzman P, et al. Effects on adolescent ATOD behaviors and attitu- } \\
\text { des of a 5-year community partnership. Evaluation and Program Planning. } \\
\text { 1997;20(3):307-313. doi:https://doi.org/10.1016/S0149-7189(97)00010-4 }\end{array}$ & $\begin{array}{l}\text { káros szenve- } \\
\text { dély }\end{array}$ & Észak-Amerika \\
\hline 20 & $\begin{array}{l}\text { Haignere CS, Freudenberg N, Silver DR, et al. One method for assessing HIV/AIDS peer- } \\
\text { education programs. J Adolesc Health. 1997;21(2):76-79 }\end{array}$ & $\begin{array}{l}\text { szexuális ne- } \\
\text { velés }\end{array}$ & Észak-Amerika \\
\hline 21 & $\begin{array}{l}\text { Sawyer RG, Pinciaro P, Bedwell, D. How peer education changed peer sexuality educa- } \\
\text { tors' self-esteem, personal development, and sexual behavior. J Am Coll Health. } \\
1997 ; 45(5): 211-217 .\end{array}$ & $\begin{array}{l}\text { szexuális ne- } \\
\text { velés }\end{array}$ & Észak-Amerika \\
\hline 22 & $\begin{array}{c}\text { Kerr RNM, MacDonald TH. Project } 2000 \text { student nurses' creative approach to peer edu- } \\
\text { cation. Nurse Educ Today. 1997;17(3):247-254. doi: https://doi.org/10.1016/S0260- } \\
6917(97) 80140-2\end{array}$ & $\begin{array}{l}\text { szexuális ne- } \\
\text { velés }\end{array}$ & Észak-Amerika \\
\hline 23 & $\begin{array}{l}\text { Telleria T. Peer education in Portugal. Adolescent health/sex education. Entre Nous Cph } \\
\text { Den. 1998;(38):13. }\end{array}$ & $\begin{array}{l}\text { szexuális ne- } \\
\text { velés }\end{array}$ & Európa \\
\hline 24 & $\begin{array}{l}\text { Early E, Battle K, Cantwell E, et al. Effect of several interventions on the frequency of } \\
\text { handwashing among elementary public school children. Am J Infect Control. } \\
\text { 1998;26(3):263-269. }\end{array}$ & higiénia & Észak-Amerika \\
\hline 25 & $\begin{array}{l}\text { Woods ER, Samples CL, Melchiono MW, et al. Boston HAPPENS Program A model of he- } \\
\text { alth care for HIV-positive, homeless, and at-risk youth. J Adolesc Health. 1998;23(2 } \\
\text { Suppl.):37-48. }\end{array}$ & $\begin{array}{l}\text { szexuális ne- } \\
\text { velés }\end{array}$ & Észak-Amerika \\
\hline 26 & $\begin{array}{l}\text { Wright ER, Gonzalez C, Werner JN, et al. Indiana Youth Access Project: A model for res- } \\
\text { ponding to the HIV risk behaviors of gay, lesbian, and bisexual youth in the Heartland. J } \\
\text { Adolesc Health. 1998;23(2):83-95. }\end{array}$ & $\begin{array}{l}\text { szexuális ne- } \\
\text { velés }\end{array}$ & Észak-Amerika \\
\hline 27 & $\begin{array}{l}\text { Hymel MS, Greenberg BL. The Walden House Young Adult HIV project: Meeting the ne- } \\
\text { eds of multidiagnosed youth. J Adolesc Health. 1998;23(2):122-131. }\end{array}$ & $\begin{array}{l}\text { szexuális ne- } \\
\text { velés }\end{array}$ & Észak-Amerika \\
\hline 28 & $\begin{array}{l}\text { Tydén T, Bergholm M, Hallén A, et al. Evaluation of an STD-prevention program for } \\
\text { Swedish university students. J Am Coll Health. 1998;47(2):70-75. }\end{array}$ & $\begin{array}{l}\text { szexuális ne- } \\
\text { velés }\end{array}$ & Európa \\
\hline 29 & $\begin{array}{l}\text { A sure thing, not just a fad: youth-to-youth approach to health and sexuality issues. } \\
\text { Adolesc Educ Newsl. 1999;2(2):19-20. }\end{array}$ & $\begin{array}{l}\text { szexuális ne- } \\
\text { velés }\end{array}$ & Ázsia \\
\hline 30 & $\begin{array}{l}\text { Sheehan K, DiCara JA, LeBailly S. et al. Adapting the Gang Model: Peer Mentoring for Vi- } \\
\text { olence Prevention. Pediatrics. 1999; 104(1 Pt 1):50-4. doi:10.1542/peds.104.1.50 }\end{array}$ & lelki egészség & Észak-Amerika \\
\hline 31 & $\begin{array}{l}\text { Yanda K. Teenagers educating teenagers about reproductive health and their rights to } \\
\text { confidential care. Fam Plann Perspect. 2000;32(5):256-257. }\end{array}$ & $\begin{array}{l}\text { szexuális ne- } \\
\text { velés }\end{array}$ & Észak-Amerika \\
\hline 32 & $\begin{array}{l}\text { Backett-Milburn K, Wilson S. Understanding peer education: insights from a process } \\
\qquad \text { evaluation. Health Educ Res. 2000;15(1):85-96. }\end{array}$ & $\begin{array}{l}\text { szexuális ne- } \\
\text { velés }\end{array}$ & Európa \\
\hline 33 & $\begin{array}{l}\text { Wolf RC, Tawfik LA, Bond KC. Peer promotion programs and social networks in Ghana: } \\
\text { methods for monitoring and evaluating AIDS prevention and reproductive health prog- } \\
\text { rams among adolescents and young adults. J Health Commun. 2000;(5 Suppl):61-80. }\end{array}$ & $\begin{array}{l}\text { szexuális ne- } \\
\text { velés }\end{array}$ & Afrika \\
\hline 34 & $\begin{array}{l}\text { Rosenfield SL, Keenan PM, Fox DJ, et al. Youth perceptions of comprehensive ado- } \\
\text { lescent health services through the Boston HAPPENS program. J Pediatr Health Care. } \\
\qquad 2000 ; 14(2): 60-67 .\end{array}$ & $\begin{array}{l}\text { általános } \\
\text { egészség }\end{array}$ & Észak-Amerika \\
\hline 35 & $\begin{array}{l}\text { Fox R. Tanzanian AIDS project works towards "good things for young people". Lancet. } \\
\qquad 2000 ; 355(9216): 1703 .\end{array}$ & $\begin{array}{l}\text { szexuális ne- } \\
\text { velés }\end{array}$ & Afrika \\
\hline 36 & Streng N. A student health advocate program. J Sch Nurs. 2000;16(5):50-53. & $\begin{array}{l}\text { általános } \\
\text { egészség }\end{array}$ & Észak-Amerika \\
\hline 37 & $\begin{array}{l}\text { Brieger WR, Delano GE, Lane CG, et al. West African youth initiative: outcome of a rep- } \\
\text { roductive health education program. J Adolesc Health. 2001;29(6):436-446. }\end{array}$ & $\begin{array}{l}\text { szexuális ne- } \\
\text { velés }\end{array}$ & Afrika \\
\hline 38 & $\begin{array}{l}\text { Gao Y, Lu ZZ, Shi R, et al. AIDS and sex education for young people in China. Reprod Fer- } \\
\text { til Dev. 2001;13(7-8):729-737. }\end{array}$ & $\begin{array}{l}\text { szexuális ne- } \\
\text { velés }\end{array}$ & Ázsia \\
\hline
\end{tabular}




\begin{tabular}{|c|c|c|c|}
\hline 39 & $\begin{array}{l}\text { Speizer IS, Tambashe BO, Tegang SP. An evaluation of the "Entre Nous Jeunes" peer- } \\
\text { educator program for adolescents in Cameroon. Stud Fam Plann. 2001;32(4):339-351. }\end{array}$ & $\begin{array}{l}\text { szexuális ne- } \\
\text { velés }\end{array}$ & Afrika \\
\hline 40 & $\begin{array}{l}\text { Campbell C, MacPhail C. Peer education, gender and the development of critical } \\
\text { consciousness: participatory HIV prevention by South African youth. Soc Sci Med. } \\
\text { 2002;55(2):331-345. }\end{array}$ & $\begin{array}{l}\text { szexuális ne- } \\
\text { velés }\end{array}$ & Afrika \\
\hline 41 & $\begin{array}{l}\text { Wolf RC, Bond KC. Exploring similarity between peer educators and their contacts and } \\
\text { AIDS-protective behaviours in reproductive health programmes for adolescents and yo- } \\
\text { ung adults in Ghana. AIDS Care. 2002;14(3):361-373. }\end{array}$ & $\begin{array}{l}\text { szexuális ne- } \\
\text { velés }\end{array}$ & Afrika \\
\hline 42 & $\begin{array}{l}\text { Szilágyi T. Peer education of tobacco issues in Hungarian communities of Roma and so- } \\
\text { cially disadvantaged children. Cent Eur J Public Health. 2002;10(3):117-120. }\end{array}$ & $\begin{array}{l}\text { káros szenve- } \\
\text { dély }\end{array}$ & $\begin{array}{l}\text { Európa (Ma- } \\
\text { gyar- } \\
\text { ország) }\end{array}$ \\
\hline 43 & $\begin{array}{c}\text { Ebreo A, Feist-Price S, Siewe Y. et al. Effects of Peer Education on the Peer Educators in } \\
\text { a School-Based HIV Prevention Program: Where Should Peer Education Research Go } \\
\text { From Here? Health Educ. Behav. 2002;29(4):411-423. } \\
\text { doi:10.1177/109019810202900402 }\end{array}$ & $\begin{array}{l}\text { szexuális ne- } \\
\text { velés }\end{array}$ & Észak-Amerika \\
\hline 44 & $\begin{array}{c}\text { Strange V, Forrest S, Oakley A. What influences peer-led sex education in the } \\
\text { classroom? A view from the peer educators. Health Educ Res. 2002;17(3):339-349. } \\
\text { doi:https://doi.org/10.1093/her/17.3.339 }\end{array}$ & $\begin{array}{l}\text { szexuális ne- } \\
\text { velés }\end{array}$ & Európa \\
\hline 45 & $\begin{array}{c}\text { Strange } V \text {, Forrest S, Oakley A, et al. Peer-led sex education-characteristics of peer } \\
\text { educators and their perceptions of the impact on them of participation in a peer educa- } \\
\text { tion programme. Health Educ Res. 2002;17(3):327-337. } \\
\text { doi:https://doi.org/10.1093/her/17.3.327 }\end{array}$ & $\begin{array}{l}\text { szexuális ne- } \\
\text { velés }\end{array}$ & Európa \\
\hline 46 & $\begin{array}{l}\text { Pearlman DN, Camberg L, Wallace LJ, et al. Tapping youth as agents for change: eva- } \\
\text { luation of a peer leadership HIV/AIDS intervention. Journal of Adolescent Health. } \\
\text { 2002;31(1):31-39. }\end{array}$ & $\begin{array}{l}\text { szexuális ne- } \\
\text { velés }\end{array}$ & Észak-Amerika \\
\hline 47 & $\begin{array}{c}\text { Woods DV. The Effect of Video-Based Peer Education on the Social Acceptability of } \\
\text { Adults With Tourette's Syndrome. J Dev Phys Disabil. 2002;14(1):51-62. } \\
\text { doi:https://doi.org/10.1023/A:1013563713146 }\end{array}$ & lelki egészség & Észak-Amerika \\
\hline 48 & $\begin{array}{l}\text { Campbell C, MacPhail C. Peer education, gender and the development of critical } \\
\text { consciousness: participatory HIV prevention by South African youth. Soc Sci Med. } \\
\text { 2002;55(2):331-345. }\end{array}$ & $\begin{array}{l}\text { szexuális ne- } \\
\text { velés }\end{array}$ & Afrika \\
\hline 49 & $\begin{array}{l}\text { Story M, Lytle LA, Bimbaum AS, et al. Peer-led, school-based nutrition education for yo- } \\
\text { ung adolescents: feasibility and process evaluation of the TEENS study. J Sch Health. } \\
\qquad 2002 ; 72(3): 121-127 .\end{array}$ & táplálkozás & Észak-Amerika \\
\hline 50 & $\begin{array}{l}\text { Marick J. HIV/AIDS peer education: a rural health project. J Sch Nurs. 2002;18(1):41-47. } \\
\text { doi:10.1177/10598405020180010801 }\end{array}$ & $\begin{array}{l}\text { szexuális ne- } \\
\text { velés }\end{array}$ & Észak-Amerika \\
\hline 51 & $\begin{array}{l}\text { Perez F, Dabis F. HIV prevention in Latin America: reaching youth in Colombia. AIDS } \\
\text { Care. } 2003 ; 15(1): 77-87 \text {. doi:10.1080/0954012021000039789 }\end{array}$ & $\begin{array}{l}\text { szexuális ne- } \\
\text { velés }\end{array}$ & Dél-Amerika \\
\hline 52 & $\begin{array}{c}\text { Ott MA, Evans NL, Halpem-Feisher BL, et al. Differences in altruistic roles and HIV risk } \\
\text { perception among staff, peer educators, and students in an adolescent peer education } \\
\text { program. AIDS Educ Prev. 2003;15(2):159-171. }\end{array}$ & $\begin{array}{l}\text { szexuális ne- } \\
\text { velés }\end{array}$ & Észak-Amerika \\
\hline 53 & $\begin{array}{l}\text { Pérez-Rodrigo C, Aranceta J. Nutrition education in schools: experiences and challenges, } \\
\text { Eur J Clin Nutr. 2003;57(Suppl 1):S82-S85. doi:10.1038/sj.ejcn.1601824 }\end{array}$ & táplálkozás & Európa \\
\hline 54 & $\begin{array}{l}\text { Okonofua FE, Copian P, Collins S, et al. Impact of an intervention to improve treatment- } \\
\text { seeking behavior and prevent sexually transmitted diseases among Nigerian youths. Int } \\
\qquad \text { J Infect Dis. } 2003 ; 7(1): 61-73 .\end{array}$ & $\begin{array}{l}\text { Szexuális ne- } \\
\text { velés }\end{array}$ & Afrika \\
\hline 55 & $\begin{array}{l}\text { Özcebe } H \text {, Akin L. Effects of peer education on reproductive health knowledge for ado- } \\
\text { lescents living in rural areas of Turkey. J Adolesc Health. 2003;33(4):217-218. }\end{array}$ & $\begin{array}{l}\text { szexuális ne- } \\
\text { velés }\end{array}$ & Ázsia \\
\hline 56 & $\begin{array}{l}\text { Caron F, Godin G, Otis J, et al. Evaluation of a theoretically based AIDS/STD peer educa- } \\
\text { tion program on postponing sexual intercourse and on condom use among adolescents } \\
\text { attending high school. Health Educ Res. 2004;19(2):185-197. } \\
\text { doi:https://doi.org/10.1093/her/cyg017 }\end{array}$ & $\begin{array}{l}\text { szexuális ne- } \\
\text { velés }\end{array}$ & Észak-Amerika \\
\hline
\end{tabular}




\begin{tabular}{|c|c|c|c|}
\hline 57 & $\begin{array}{l}\text { Kinsler J, Sneed CD, Morisky DE, et al. Evaluation of a school-based intervention for } \\
\text { HIV/AIDS prevention among Belizean adolescents. Health Educ Res. 2004;19(6):730- } \\
\text { 738. doi:https://doi.org/10.1093/her/cyg091 }\end{array}$ & $\begin{array}{l}\text { szexuális ne- } \\
\text { velés }\end{array}$ & Dél-Amerika \\
\hline 58 & $\begin{array}{l}\text { Ajoko DC, Salami KK, Brieger WR. The process of involving high school students in deve- } \\
\text { loping reproductive health education materials in Ibadan, Nigeria. Int Q Community He- } \\
\text { alth Educ. 2004;22(3):167-187. }\end{array}$ & $\begin{array}{l}\text { szexuális ne- } \\
\text { velés }\end{array}$ & Afrika \\
\hline 59 & $\begin{array}{l}\text { Agha S, Van Rossem R. Impact of a school-based peer sexual health intervention on nor- } \\
\text { mative beliefs, risk perceptions, and sexual behavior of Zambian adolescents. J Adolesc } \\
\text { Health. 2004;34(5):441-452. }\end{array}$ & $\begin{array}{l}\text { szexuális ne- } \\
\text { velés }\end{array}$ & Afrika \\
\hline 60 & $\begin{array}{c}\text { Özcebe H, Akin L, Aslan D. A peer education example on HIV/AIDS at a high school in An- } \\
\text { kara. Turk J Pediatr. 2004;45(1):54-59. }\end{array}$ & $\begin{array}{l}\text { szexuális ne- } \\
\text { velés }\end{array}$ & Ázsia \\
\hline 61 & $\begin{array}{l}\text { Sevil U, Atan SU, Kiris H, et al. Peer education project on breast self-examination in Iz- } \\
\text { mir, Turkey. Asian Pac J Cancer Prev. 2005;6(1):29-32. }\end{array}$ & betegség & Ázsia \\
\hline 62 & $\begin{array}{l}\text { Taylor JP, Mckenna M, Evers S. Determinants of healthy eating in children and youth, } \\
\text { Can J Public Health. 2005;96(Suppl.3):S20-26. }\end{array}$ & táplálkozás & Észak-Amerika \\
\hline 63 & $\begin{array}{c}\text { Ergene T, Cok F, Tüner A, et al. A controlled-study of preventive effects of peer educa- } \\
\text { tion and single-session lectures on HIV/AIDS knowledge and attitudes among university } \\
\text { students in Turkey. AIDS Educ Prev. 2005;17(3):268-278. } \\
\text { doi:10.1521/aeap.17.4.268.66533 }\end{array}$ & $\begin{array}{l}\text { szexuális ne- } \\
\text { velés }\end{array}$ & Ázsia \\
\hline 64 & $\begin{array}{l}\text { Mikhailovich K, Arabena K. Evaluating an indigenous sexual health peer education pro- } \\
\text { ject. Health Promot J Austr. 2005;16(3):189-193. }\end{array}$ & $\begin{array}{l}\text { szexuális ne- } \\
\text { velés }\end{array}$ & Ausztrália \\
\hline 65 & $\begin{array}{l}\text { Delp L, Brown M, Domenzain A. Fostering youth leadership to address workplace and } \\
\text { community environmental health issues: a university-school-community partnership. } \\
\text { Health Promot Pract. 2005;6(3):270-285. doi:10.1177/1524839904266515 }\end{array}$ & $\begin{array}{l}\text { általános } \\
\text { egészség }\end{array}$ & Észak-Amerika \\
\hline 66 & $\begin{array}{l}\text { Parwej S, Kumar R, Walia I, et al. Reproductive health education intervention trial. In- } \\
\text { dian J Pediatr. 2005;72(4):287-291. }\end{array}$ & $\begin{array}{l}\text { szexuális ne- } \\
\text { velés }\end{array}$ & Ázsia \\
\hline 67 & $\begin{array}{l}\text { Borgia P, Marinacci C, Schifano P, et al. Is peer education the best approach for HIV pre- } \\
\text { vention in schools? Findings from a randomized controlled trial. J Adolesc Health. } \\
\qquad 2005 ; 36(6): 508-516 \text {. doi:10.1016/j.jadohealth.2004.03.005 }\end{array}$ & $\begin{array}{l}\text { szexuális ne- } \\
\text { velés }\end{array}$ & Európa \\
\hline 68 & $\begin{array}{l}\text { Rampersaud GC, Metzl JD, Pereira M, et al. Breakfast Habits, Nutritional Status, Body } \\
\text { Weight, and Academic Performance in Children and Adolescents, J Am Diet Assoc. } \\
\text { 2005;105(5):743-760. doi:10.1016/j.jada.2005.02.007 }\end{array}$ & táplálkozás & Észak-Amerika \\
\hline 69 & $\begin{array}{l}\text { Campbell S. Using peer education projects to prevent HIV/AIDS in young people. Nurs } \\
\text { Stand. 2005;20(10):50-55. doi:10.7748/ns2005.11.20.10.50.c4005 }\end{array}$ & $\begin{array}{l}\text { szexuális ne- } \\
\text { velés }\end{array}$ & Afrika \\
\hline 70 & $\begin{array}{l}\text { Merakou K, Kourea-Kremastinou J. Peer education in HIV prevention: an evaluation in } \\
\text { schools. Eur J Public Health. 2006;16(2):128-132. doi:10.1093/eurpub/cki162 }\end{array}$ & $\begin{array}{l}\text { szexuális ne- } \\
\text { velés }\end{array}$ & Európa \\
\hline 71 & $\begin{array}{c}\text { Audrey S, Holliday J, Parry-Langdon N, et al. Meeting the challenges of implementing } \\
\text { process evaluation within randomized controlled trials: the example of ASSIST (A Stop } \\
\text { Smoking in Schools Trial). Health Educ Res. 2006;21(3):366-377. } \\
\text { doi:https://doi.org/10.1093/her/cyl029 }\end{array}$ & $\begin{array}{l}\text { káros szenve- } \\
\text { dély }\end{array}$ & Európa \\
\hline 72 & $\begin{array}{l}\text { Frederick K, Barlow J. The Citizenship Safety Project: a pilot study. Health Educ Res. } \\
\text { 2006;21(1):87-96. doi:https://doi.org/10.1093/her/cyh046 }\end{array}$ & $\begin{array}{l}\text { elsősegély, } \\
\text { baleset }\end{array}$ & Európa \\
\hline 73 & $\begin{array}{c}\text { Cartagena RG, Veugelers PJ, Kipp W, et al. Effectiveness of an HIV Prevention Program } \\
\text { for Secondary School Students in Mongolia. J Adolesc Health. 2006;39(6):925.e9- } \\
\text { 925.e16 }\end{array}$ & $\begin{array}{l}\text { szexuális ne- } \\
\text { velés }\end{array}$ & Ázsia \\
\hline 74 & $\begin{array}{c}\text { Erulkar AS, Mekbib TA, Simie N, et al. Differential use of adolescent reproductive health } \\
\text { programs in Addis Ababa, Ethiopia. J Adolesc Health. 2006;38(3):253-260. } \\
\text { doi:10.1016/j.jadohealth.2005.03.026 }\end{array}$ & $\begin{array}{l}\text { szexuális ne- } \\
\text { velés }\end{array}$ & Afrika \\
\hline 75 & $\begin{array}{l}\text { Evans DL, Tripp JH. Sex education: The case for primary prevention and peer education. } \\
\text { Current Paediatrics. 2006;16(2):95-99. doi:https://doi.org/10.1016/j.cupe.2005.12.007 }\end{array}$ & $\begin{array}{l}\text { szexuális ne- } \\
\text { velés }\end{array}$ & Európa \\
\hline
\end{tabular}




\begin{tabular}{|c|c|c|c|}
\hline 76 & $\begin{array}{l}\text { Pbert L, Fletcher KE, Flint AJ, et al. Smoking Prevention and Cessation Intervention Deliv- } \\
\text { ery by Pediatric Providers, as Assessed with Patient Exit Interviews. Pediatrics. } \\
\text { 2006;118(3):e810-24. doi:10.1542/peds.2005-2869 }\end{array}$ & $\begin{array}{l}\text { káros szenve- } \\
\text { dély }\end{array}$ & Észak-Amerika \\
\hline 77 & $\begin{array}{l}\text { Audrey S, Holliday J, Campbell R. It's good to talk: adolescent perspectives of an infor- } \\
\text { mal, peer-led intervention to reduce smoking. Soc Sci Med. 2006;63(2):320-334. } \\
\text { doi:10.1016/j.socscimed.2005.12.010 }\end{array}$ & $\begin{array}{l}\text { káros szenve- } \\
\text { dély }\end{array}$ & Európa \\
\hline 78 & $\begin{array}{l}\text { Ajuwon AJ, Brieger WR. Evaluation of a school-based reproductive health education } \\
\text { program in rural South Western, Nigeria. Afr J Reprod Health. 2007;11(2):47-59. }\end{array}$ & $\begin{array}{l}\text { szexuális ne- } \\
\text { velés }\end{array}$ & Afrika \\
\hline 79 & $\begin{array}{l}\text { Valente TW, Okamoto J, Pumpuang P, et al. Differences in Perceived Implementation of } \\
\text { a Standard Versus Peer-led Interactive Substance Abuse Prevention Program. Am J He- } \\
\text { alth Behav. 2007;31(3):297-311. doi:10.5555/ajhb.2007.31.3.297. }\end{array}$ & $\begin{array}{l}\text { káros szenve- } \\
\text { dély }\end{array}$ & Észak-Amerika \\
\hline 80 & $\begin{array}{l}\text { Roblyn L. Childhood obesity: Food, nutrient, and eating-habit trends and influences. } \\
\text { Appl Physiol Nutr Metab. 2007;32(4):635-645. doi:10.1139/H07-046 }\end{array}$ & táplálkozás & Észak-Amerika \\
\hline 81 & $\begin{array}{l}\text { Malak AT, Dicle A. Assessing the efficacy of a peer education model in teaching breast } \\
\text { self-examination to university students. Asian Pac J Cancer Prev. 2007;8(4):481-484. }\end{array}$ & betegség & Ázsia \\
\hline 82 & $\begin{array}{l}\text { Ozer EJ, Weinstein RS, Maslach C, et al. Adolescent AIDS prevention in context: the im- } \\
\text { pact of peer educator qualities and classroom environments on intervention efficacy. } \\
\text { Am J Community Psychol. 1997;25(3):289-323. }\end{array}$ & $\begin{array}{l}\text { szexuális ne- } \\
\text { velés }\end{array}$ & Észak-Amerika \\
\hline 83 & $\begin{array}{l}\text { Plummer ML, Wight D, Obasi Al, et al. A process evaluation of a school-based ado- } \\
\text { lescent sexual health intervention in rural Tanzania: the MEMA kwa Vijana programme. } \\
\text { Health Educ Res. 2007;22(4):500-512. doi:https://doi.org/10.1093/her/cyl103 }\end{array}$ & $\begin{array}{l}\text { szexuális ne- } \\
\text { velés }\end{array}$ & Afrika \\
\hline 84 & $\begin{array}{l}\text { Jodati AR, Nourabadi GR, Hassanzadeh S, et al. Impact of education in promoting the } \\
\text { knowledge of and attitude to HIV/AIDS prevention: a trial on 17,000 Iranian students. } \\
\text { Int J STD AIDS. 2007;18(6):407-409. doi:10.1258/095646207781024829 }\end{array}$ & $\begin{array}{l}\text { szexuális ne- } \\
\text { velés }\end{array}$ & Ázsia \\
\hline 85 & $\begin{array}{l}\text { Clark HR, Goyder E, Bissell P, et al. How do parents' child-feeding behaviours influence } \\
\text { child weight? Implications for childhood obesity policy. J Publ Health. 2007;29(2):132- } \\
\text { 141. doi:10.1093/pubmed/fdm012 }\end{array}$ & táplálkozás & Európa \\
\hline 86 & $\begin{array}{l}\text { Fongkaew W, Fongkaew K, Suchaxaya, P. Early Adolescent Peer Leader Development in } \\
\text { HIV Prevention Using Youth-Adult Partnership With Schools Approach. J Assoc Nurses } \\
\text { AIDS Care. 2007;18(2):60-71. doi:10.1016/j.jana.2007.01.005 }\end{array}$ & $\begin{array}{l}\text { szexuális ne- } \\
\text { velés }\end{array}$ & Ázsia \\
\hline 87 & $\begin{array}{l}\text { Stock S, Miranda C, Evans S. et al. Healthy Buddies: A Novel, Peer-Led Health Promotion } \\
\text { Program for the Prevention of Obesity and Eating Disorders in Children in Elementary } \\
\text { School. Pediatrics. 2007;120(4):e1059-68. doi:10.1542/peds.2006-3003 }\end{array}$ & táplálkozás & Észak-Amerika \\
\hline 88 & $\begin{array}{l}\text { Aslan D, Sahin A. Adolescent peers and anti-smoking activities. Promot Educ. } \\
\qquad 2007 ; 14(1): 36-40 .\end{array}$ & $\begin{array}{l}\text { káros szenve- } \\
\text { dély }\end{array}$ & Ázsia \\
\hline 89 & $\begin{array}{l}\text { Visser MJ. HIV/AIDS prevention through peer education and support in secondary } \\
\text { schools in South Africa. SAHARA J. 2007;4(3):678-694. }\end{array}$ & $\begin{array}{l}\text { szexuális ne- } \\
\text { velés }\end{array}$ & Afrika \\
\hline 90 & $\begin{array}{l}\text { Fenn J, Rosales C, Logue C. "Sir insulin monk versus the evil Diana betes": a program } \\
\text { addressing type } 2 \text { diabetes education and prevention in youth. Diabetes Educ. } \\
\qquad 2007 ; 33(3): 455-456 \text {. doi:10.1177/0145721707301910 }\end{array}$ & táplálkozás & Észak-Amerika \\
\hline 91 & $\begin{array}{l}\text { Streng NJ. A follow-up study of former student health advocates. J Sch Nurs. } \\
\text { 2007;23(6):353-358. doi:10.1177/10598405070230060901 }\end{array}$ & $\begin{array}{l}\text { általános } \\
\text { egészség }\end{array}$ & Észak-Amerika \\
\hline 92 & $\begin{array}{c}\text { Mahat G, Scoloveno Ma, De Leon T, et al. Preliminary Evidence of an Adolescent } \\
\text { HIV/AIDS Peer Education Program. J Pediatr Nurs. 2007;23(5):358-363. } \\
\text { doi:10.1016/j.pedn.2007.12.007 }\end{array}$ & $\begin{array}{l}\text { szexuális ne- } \\
\text { velés }\end{array}$ & Észak-Amerika \\
\hline 93 & $\begin{array}{l}\text { Mevsim V, Guldal D, Ozcakar, N. et al. What was retained? The assessment of the trai- } \\
\text { ning for the peer trainers' course on short and long term basis. BMC Public Health. } \\
\text { 2008;(8):24. doi:10.1186/1471-2458-8-24. }\end{array}$ & $\begin{array}{l}\text { szexuális ne- } \\
\text { velés }\end{array}$ & Ázsia \\
\hline
\end{tabular}




\begin{tabular}{|c|c|c|c|}
\hline 94 & $\begin{array}{c}\text { McWhirther J, McCann D, Coleman H, et al. Can schools promote the health of children } \\
\text { with asthma? Health Educ Res. 2008;23(6):917-930. } \\
\text { doi:https://doi.org/10.1093/her/cym081 }\end{array}$ & betegség & Európa \\
\hline 95 & $\begin{array}{l}\text { Cebotarenco N, Bush PJ. Reducing antibiotics for colds and flu: a student-taught prog- } \\
\text { ram. Health Educ Res. 2008;23(1):146-157. doi:https://doi.org/10.1093/her/cym008 }\end{array}$ & betegség & Európa \\
\hline 96 & $\begin{array}{l}\text { Shen LX, Hong H, Cai Y, et al. Effectiveness of peer education in HIV/STD prevention at } \\
\text { different types of senior high schools in Shanghai, People's Republic of China. Int J STD } \\
\text { AIDS. 2008;19(11):761-767. doi:10.1258/ijsa.2008.008053 }\end{array}$ & $\begin{array}{l}\text { szexuális ne- } \\
\text { velés }\end{array}$ & Ázsia \\
\hline 97 & $\begin{array}{c}\text { Cai Y, Hong H, Shi R, et al. Long-term follow-up study on peer-led school-based HIV/AIDS } \\
\text { prevention among youths in Shanghai. Int J STD AIDS. 2008;19(12):848-50. } \\
\text { doi:10.1258/ijsa.2008.008129 }\end{array}$ & $\begin{array}{l}\text { szexuális ne- } \\
\text { velés }\end{array}$ & Ázsia \\
\hline 98 & $\begin{array}{l}\text { Miller AN, Mutungi M, Facchini E, et al. An outcome assessment of an ABC-based HIV } \\
\text { peer education intervention among Kenyan university students. J Health Commun. } \\
\text { 2008;13(4):345-56. doi:10.1080/10810730802063470 }\end{array}$ & $\begin{array}{l}\text { szexuális ne- } \\
\text { velés }\end{array}$ & Afrika \\
\hline 99 & $\begin{array}{c}\text { Lo E, Coles R, Humber ML, et al. Beverage intake improvement by high school students } \\
\text { in Saskatchewan, Canada. Nutr Res. 2008;28(3):144-150. doi:10.1016/j.nut- } \\
\text { res.2008.01.005 }\end{array}$ & táplálkozás & Észak-Amerika \\
\hline 100 & $\begin{array}{c}\text { Klatt C, Berg CJ, Thomas JL, et al. The role of peer e-mail support as part of a college } \\
\text { smoking-cessation website. Am J Prev Med. 2008;35(6 Suppl):S471-8. } \\
\text { doi:10.1016/j.amepre.2008.09.001. }\end{array}$ & $\begin{array}{l}\text { káros szenve- } \\
\text { dély }\end{array}$ & Észak-Amerika \\
\hline 101 & $\begin{array}{l}\text { Pbert L, Flint AJ, Fletcher KE, et al. Effect of a Pediatric Practice-Based Smoking Pre- } \\
\text { vention and Cessation Intervention for Adolescents: A Randomized, Controlled Trial. Pe- } \\
\text { diatrics. 2008;121(4):e738-47. doi:10.1542/peds.2007-1029 }\end{array}$ & $\begin{array}{c}\text { káros szenve- } \\
\text { dély }\end{array}$ & Észak-Amerika \\
\hline 102 & $\begin{array}{l}\text { Posner J, Kayastha P, Davis D, et al. Development of leadership self-efficacy and } \\
\text { collective efficacy: adolescent girls across castes as peer educators in Nepal. Glob Public } \\
\text { Health. 2009;4(3):284-302. doi:10.1080/17441690902783157 }\end{array}$ & $\begin{array}{l}\text { szexuális ne- } \\
\text { velés }\end{array}$ & Ázsia \\
\hline 103 & $\begin{array}{l}\text { van der Maas F, Otte WM. Evaluation of HIV/AIDS secondary school peer education in } \\
\text { rural Nigeria. Health Educ Res. 2009;24(4):547-557. } \\
\text { doi:https://doi.org/10.1093/her/cyn056 }\end{array}$ & $\begin{array}{l}\text { szexuális ne- } \\
\text { velés }\end{array}$ & Afrika \\
\hline 104 & $\begin{array}{l}\text { Starkey F, Audrey S, Holliday, J, et al. Identifying influential young people to undertake } \\
\text { effective peer-led health promotion: the example of A Stop Smoking In Schools Trial } \\
\text { (ASSIST). Health Educ Res. 2009;24(6):977-988. doi:https://doi.org/10.1093/her/cyp045 }\end{array}$ & $\begin{array}{l}\text { káros szenve- } \\
\text { dély }\end{array}$ & Európa \\
\hline 105 & $\begin{array}{l}\text { Li LP, Chow KW, Griffiths S, et al. University Based Peer Health Education in China: The } \\
\text { Shantou Experience. J Am Coll Health. 2009;57(5):549-551. doi:10.3200/JACH.57.5.549- } \\
552\end{array}$ & $\begin{array}{l}\text { általános } \\
\text { egészség }\end{array}$ & Ázsia \\
\hline 106 & $\begin{array}{l}\text { Groes-Green C. Safe sex pioneers: class identity, peer education and emerging masculi- } \\
\text { nities among youth in Mozambique. Sex Health. 2009;6(3):233-240. } \\
\text { doi:10.1071/SH09021 }\end{array}$ & $\begin{array}{l}\text { szexuális ne- } \\
\text { velés }\end{array}$ & Afrika \\
\hline 107 & $\begin{array}{l}\text { McCrerary LL, Kaponda CP, Kafulafula UK, et al. Process evaluation of HIV prevention } \\
\text { peer groups in Malawi: a look inside the black box. Health Educ Res. 2010;25(6):965- } \\
\text { 978. doi:https://doi.org/10.1093/her/cyq049 }\end{array}$ & $\begin{array}{l}\text { szexuális ne- } \\
\text { velés }\end{array}$ & Afrika \\
\hline 108 & $\begin{array}{l}\text { Lotean LM, Dijk F, Mesters I, et al. Evaluation of a peer-led smoking prevention prog- } \\
\text { ramme for Romanian adolescents. Health Educ Res. 2010;25(5):803-814. } \\
\text { doi:https://doi.org/10.1093/her/cyq034 }\end{array}$ & $\begin{array}{l}\text { káros szenve- } \\
\text { dély }\end{array}$ & Európa \\
\hline 109 & $\begin{array}{l}\text { Al-Iryani B, Al-Sakkaf K, Basaleem H, et al. Process evaluation of a three-year commu- } \\
\text { nity-based peer education intervention for HIV prevention among Yemeni young } \\
\text { people. Int Q Community Health Educ. 2010;31(2):133-54. doi:10.2190/IQ.31.2.C }\end{array}$ & $\begin{array}{c}\text { szexuális ne- } \\
\text { velés }\end{array}$ & Ázsia \\
\hline 110 & $\begin{array}{l}\text { Li S, Huang H, Cai Y, et al. Evaluation of a school-based HIV/AIDS peer-led prevention } \\
\text { programme: the first intervention trial for children of migrant workers in China. Int J } \\
\text { STD AIDS. 2010;21(2):82-6. doi:10.1258/ijsa.2009.008514 }\end{array}$ & $\begin{array}{c}\text { szexuális ne- } \\
\text { velés }\end{array}$ & Ázsia \\
\hline 111 & $\begin{array}{l}\text { Balaji M, Andrews T, Andrew G, et al. The Acceptability, Feasibility, and Effectiveness of } \\
\text { a Population-based Intervention to Promote Youth Health: An Exploratory Study in Goa, } \\
\text { India. J Adolesc Health. 2010;48(5):453-460. doi:10.1016/j.jadohealth.2010.07.029 }\end{array}$ & $\begin{array}{l}\text { általános } \\
\text { egészség }\end{array}$ & Ázsia \\
\hline
\end{tabular}




\begin{tabular}{|c|c|c|c|}
\hline 112 & $\begin{array}{l}\text { Puskar KR, Stark KH, Northcut T, et al. Teaching kids to cope with anger: Peer education. } \\
\text { J Child Health Care. 2010;15(1):5-13. doi:10.1177/1367493510382932 }\end{array}$ & lelki egészség & Észak-Amerika \\
\hline 113 & $\begin{array}{l}\text { Arevian M. Training trainees, young activists, to conduct awareness campaigns about } \\
\text { prevention of substance abuse among Lebanese/Armenian young people. J Interprof } \\
\text { Care. } 2010 ; 24(2): 173-182 \text {. doi:10.1080/13561820903078157 }\end{array}$ & $\begin{array}{l}\text { káros szenve- } \\
\text { dély }\end{array}$ & Ázsia \\
\hline 114 & $\begin{array}{c}\text { Elledge LC, Cavell TA, Ogle NT, et al. Newgent School-Based Mentoring as Selective Pre- } \\
\text { vention for Bullied Children: A Preliminary Test J Primary Prevent. 2010;(31):171-187. } \\
\text { doi:10.1007/s10935-010-0215-7 }\end{array}$ & lelki egészség & Észak-Amerika \\
\hline 115 & $\begin{array}{l}\text { Horváth DA, Dombi AZS, Fésűs SZ, et al. HuMánia - Önkéntes kortársképzés a jövő orvo- } \\
\text { saiért. LAM. 2010;20(3-4):252-255. }\end{array}$ & lelki egészség & $\begin{array}{l}\text { Európa (Ma- } \\
\text { gyar- } \\
\text { ország) }\end{array}$ \\
\hline 116 & $\begin{array}{l}\text { Okanlawon FA, Asuzu MC. Effect of peer education intervention on secondary school } \\
\text { adolescents' reproductive health knowledge Saki, Nigeria. Afr J Med Med Sci. } \\
\qquad 2011 ; 40(4): 353-360 .\end{array}$ & $\begin{array}{l}\text { szexuális ne- } \\
\text { velés }\end{array}$ & Afrika \\
\hline 117 & $\begin{array}{l}\text { Scaglioni S, Arrizza C, Vecchi F, et al. Determinants of children's eating behavior. Am J } \\
\text { Clin Nutr. 2011;94(suppl):2006S-2011S. doi:10.3945/ajcn.110.001685 }\end{array}$ & táplálkozás & Európa \\
\hline 118 & $\begin{array}{c}\text { Al-Iryani B, Basaleem H, Al-Sakkaf K, et al. (2011) Evaluation of a school-based HIV pre- } \\
\text { vention intervention among Yemeni adolescents. BMC Public Health. 2011;(11):279. } \\
\text { doi:10.1186/1471-2458-11-279 }\end{array}$ & $\begin{array}{l}\text { szexuális ne- } \\
\text { velés }\end{array}$ & Ázsia \\
\hline 119 & $\begin{array}{l}\text { Kernsmith PD, Hernandez-Jozefowicz DM. A Gender-Sensitive Peer Education Program } \\
\text { for Sexual Assault Prevention in the Schools. Children \& Schools. 2011;33(3):146-157. }\end{array}$ & $\begin{array}{l}\text { szexuális ne- } \\
\text { velés }\end{array}$ & Észak-Amerika \\
\hline 120 & $\begin{array}{l}\text { Mason-Jones AJ, Flisher AJ, Mathews C. Who are the peer educators? HIV prevention in } \\
\text { South African schools. Health Educ Res. 2011;26(3):563-571. } \\
\text { doi:https://doi.org/10.1093/her/cyq064 }\end{array}$ & $\begin{array}{l}\text { szexuális ne- } \\
\text { velés }\end{array}$ & Afrika \\
\hline 121 & $\begin{array}{c}\text { Coleman KJ, Clark AY, Shordon M, et al. Teen Peer Educators and Diabetes Knowledge } \\
\text { of Low-Income Fifth Grade Students. J Community Health. 2011;(36):23-26. } \\
\text { doi:10.1007/s10900-010-9276-z }\end{array}$ & táplálkozás & Észak-Amerika \\
\hline 122 & $\begin{array}{l}\text { Faith MA, Fiala SE, Cavell, TA, et al. Mentoring Highly Aggressive Children: Pre-Post } \\
\text { Changes in Mentors' Attitudes, Personality, and Attachment Tendencies. J Prim Prev. } \\
\text { 2011;32(5):253-270. doi:10.1007/s10935-011-0254-8 }\end{array}$ & lelki egészség & Észak-Amerika \\
\hline 123 & $\begin{array}{l}\text { Mahat G, Scoloveno MA, Ayres C. HIV/AIDS knowledge and self-efficacy among } \\
\text { Nepalese adolescents: a peer education program. Res Theory Nurs Pract. } \\
\text { 2011;25(4):271-283. }\end{array}$ & $\begin{array}{l}\text { szexuális ne- } \\
\text { velés }\end{array}$ & Ázsia \\
\hline 124 & $\begin{array}{l}\text { Acemoglu H, Palanci Y, Set T, et al. An intervention study for viral hepatitis. Peer-led he- } \\
\text { alth education among high school students. Saudi Med J. 2011;32(2):183-187. }\end{array}$ & higiénia & Ázsia \\
\hline 125 & $\begin{array}{l}\text { Michielsen K, Beauclair R, Delva W, et al. Effectiveness of a peer-led HIV prevention in- } \\
\text { tervention in secondary schools in Rwanda: results from a non-randomized controlled } \\
\text { trial. BMC Public Health. 20121;12:729. doi:10.1186/1471-2458-12-729 }\end{array}$ & $\begin{array}{l}\text { szexuális ne- } \\
\text { velés }\end{array}$ & Afrika \\
\hline 126 & $\begin{array}{l}\text { Denison JA, Tsui S, Bratt J, et al. Do peer educators make a difference? An evaluation of } \\
\text { a youth-led HIV prevention model in Zambian Schools. Health Educ Res. } \\
\text { 2012;27(2):237-247. doi:https://doi.org/10.1093/her/cyr093 }\end{array}$ & $\begin{array}{l}\text { szexuális ne- } \\
\text { velés }\end{array}$ & Afrika \\
\hline 127 & $\begin{array}{l}\text { Párduczné Szöllősi A. A kortársoktatás szerepe az egészségnevelésben. Egészségfejlesz- } \\
\text { tés. 2012;8(5-6):10-13. }\end{array}$ & $\begin{array}{l}\text { általános } \\
\text { egészség }\end{array}$ & $\begin{array}{l}\text { Európa (Ma- } \\
\text { gyar- } \\
\text { ország) }\end{array}$ \\
\hline 128 & $\begin{array}{c}\text { Rosta E, Almási Zs, Karácsony l, et al. Orvostanhallgatók egészség-magatartása. Mentál- } \\
\text { higiénés készségfejlesztés a hazai orvosképzésben. Orv. Hetil. 2012;(153):1153-1157. } \\
\text { doi:10.1556/OH.2012.29374 }\end{array}$ & lelki egészség & $\begin{array}{l}\text { Európa (Ma- } \\
\text { gyar- } \\
\text { ország) }\end{array}$ \\
\hline
\end{tabular}




\begin{tabular}{|c|c|c|c|}
\hline 129 & $\begin{array}{c}\text { Al-sheyab N, Gallagher R, Crips J. et al. Peer-led Education for Adolescents with Asthma } \\
\text { in Jordan: A Cluster-Randomized Controlled Trial. Pediatrics. 2012;129(1):e106-12. } \\
\text { doi:10.1542/peds.2011-0346 }\end{array}$ & betegség & Ázsia \\
\hline 130 & $\begin{array}{l}\text { Swartz S, Deutsch C, Makoae M, et al. Measuring change in vulnerable adolescents: } \\
\text { findings from a peer education evaluation in South Africa. SAHARA J. 2012;9(4):242-54. } \\
\text { doi:10.1080/17290376.2012.745696 }\end{array}$ & $\begin{array}{l}\text { szexuális ne- } \\
\text { velés }\end{array}$ & Afrika \\
\hline 131 & $\begin{array}{l}\text { Lardoux S, N'bouke A. Reaching adolescents and youth in Burkina Faso, Guinea-Bissau } \\
\text { and Mauritania. Afr J Reprod Health. 2013;17(1):73-84. }\end{array}$ & $\begin{array}{l}\text { szexuális ne- } \\
\text { velés }\end{array}$ & Afrika \\
\hline 132 & $\begin{array}{c}\text { Mackesi-Amiti M, Finnegan } L \text {, Ouellet } L \text {, et al. Peer-education intervention to reduce } \\
\text { injection risk behaviors benefits high-risk young injection drug users: a latent transition } \\
\text { analysis of the CIDUS 3/DUIT study. AIDS Behav. 2013;17(6):2075-2083. } \\
\text { doi:10.1007/s10461-012-0373-0 }\end{array}$ & $\begin{array}{l}\text { káros szenve- } \\
\text { dély }\end{array}$ & Észak-Amerika \\
\hline 133 & $\begin{array}{l}\text { Waterlander WE, de Boer MR, Schuit AJ, et al. Price discounts significantly enhance fruit } \\
\text { and vegetable purchases. Am J Clin Nutr. 2013;97:886-895. } \\
\text { doi:10.3945/ajcn.112.041632 }\end{array}$ & táplálkozás & Európa \\
\hline 134 & $\begin{array}{l}\text { Keeler LA, Clifford DE, August B, et al. Examination of a Peer-Led, Non-Diet Nutrition } \\
\text { and Exercise Adherence Pilot Program on a College Campus: FitU. Calif J Health Promot. } \\
\text { 2013;11(1):84-96. }\end{array}$ & táplálkozás & Észak-Amerika \\
\hline 135 & $\begin{array}{l}\text { Gittlesohn J, Dennisuk LA, Christiansen K, et al. Development and implementation of } \\
\text { Baltimore Healthy Eating Zones: a youth-targeted intervention to improve the urban } \\
\text { food environment. Health Educ Res. 2013;28(4):732-744. } \\
\text { doi:https://doi.org/10.1093/her/cyt066 }\end{array}$ & táplálkozás & Észak-Amerika \\
\hline 136 & $\begin{array}{l}\text { Kime N, McKenna J, Webster L. Young people's participation in the development of a } \\
\text { self-care intervention-a multi-site formative research study. Health Educ Res. } \\
\qquad \text { 2013;28(3):552-562. doi:https://doi.org/10.1093/her/cys107 }\end{array}$ & betegség & Európa \\
\hline 137 & $\begin{array}{l}\text { Woodbury MG, Botros M, Kuhnke JL, et al. Evaluation of a peer-led self-management } \\
\text { education programme PEP Talk: Diabetes, Healthy Feet and You. Int Wound J. } \\
\qquad 2013 ; 10(6): 703-11 \text {. doi:10.1111/iwj.12188 }\end{array}$ & táplálkozás & Észak-Amerika \\
\hline 138 & $\begin{array}{c}\text { Mason-Jones AJ, Flisher AJ, Mathews C. Peer education training for sexual health and } \\
\text { well-being in public high schools in South Africa: Is it enough to change peer educators } \\
\text { themselves? J Child Adolesc Ment Health. 2013;25(1):35-42. } \\
\text { doi:10.2989/17280583.2012.730998 }\end{array}$ & $\begin{array}{l}\text { szexuális ne- } \\
\text { velés }\end{array}$ & Afrika \\
\hline 139 & $\begin{array}{l}\text { Al-Iryani B, Basaleem H, Al-Sakkaf K, et al. Process evaluation of school-based peer edu- } \\
\text { cation for HIV prevention among Yemeni adolescents. SAHARA J. 2013;10(1):55-64. } \\
\text { doi:10.1080/17290376.2012.745294 }\end{array}$ & $\begin{array}{l}\text { szexuális ne- } \\
\text { velés }\end{array}$ & Ázsia \\
\hline 140 & $\begin{array}{l}\text { Tebbets C, Redwine D. Beyond the clinic walls: empowering young people through Yo- } \\
\text { uth Peer Provider programmes in Ecuador and Nicaragua. Reprod Health Matters. } \\
\qquad 2013 ; 21(41): 143-53 \text {. doi:10.1016/S0968-8080(13)41693-2 }\end{array}$ & $\begin{array}{l}\text { szexuális ne- } \\
\text { velés }\end{array}$ & Dél-Amerika \\
\hline 141 & $\begin{array}{c}\text { Strack Neves GC, Nasr A, Abreau-Reis P, et al. Peer health education for injury pre- } \\
\text { vention: a cost-effective measure that can spread medical knowledge amongst children } \\
\text { and youths. Scand J Trauma Resusc Emerg Med. 2013;21(Suppl. 1):S23. } \\
\text { doi:10.1186/1757-7241-21-S1-S23 }\end{array}$ & $\begin{array}{l}\text { elsősegély, } \\
\text { baleset }\end{array}$ & Dél-Amerika \\
\hline 142 & $\begin{array}{l}\text { Holsen I, Larsen T, Tjomsland HE, et al. Exploring the importance of peers as leaders in } \\
\text { the Dream School Program: from the perspectives of peer leaders, teachers and princi- } \\
\text { pals. Adv Sch Ment Health Promot. 2014;8(1):4-16. } \\
\text { doi:10.1080/1754730X.2014.978550 }\end{array}$ & lelki egészség & Európa \\
\hline 143 & $\begin{array}{l}\text { Aarø LE, Mathews C, Kaaya S, et al. Promoting sexual and reproductive health among } \\
\text { adolescents in southern and eastern Africa (PREPARE): project design and conceptual } \\
\text { framework. BMC Public Health. 2014;(14):54. doi:10.1186/1471-2458-14-54 }\end{array}$ & $\begin{array}{l}\text { szexuális ne- } \\
\text { velés }\end{array}$ & Afrika \\
\hline 144 & $\begin{array}{l}\text { Jemmott LS, Jemott JB, Ngwane Z, et al. 'Let Us Protect Our Future' a culturally congru- } \\
\text { ent evidenced-based HIV/STD risk-reduction intervention for young South African ado- } \\
\text { lescents. Health Educ Res. 2014;29(1):166-181. doi:https://doi.org/10.1093/her/cyt072 }\end{array}$ & $\begin{array}{l}\text { szexuális ne- } \\
\text { velés }\end{array}$ & Afrika \\
\hline
\end{tabular}




\begin{tabular}{|c|c|c|c|}
\hline 145 & $\begin{array}{l}\text { Jennings JM, Howard S, Perotte CL. Effects of a school-based sexuality education prog- } \\
\text { ram on peer educators: the Teen PEP model. Health Educ Res. 2014;29(2):319-329. } \\
\text { doi:https://doi.org/10.1093/her/cyt153 }\end{array}$ & $\begin{array}{l}\text { szexuális ne- } \\
\text { velés }\end{array}$ & Észak-Amerika \\
\hline 146 & $\begin{array}{l}\text { Calloway DS, Long-White DN, Corbin DE. Reducing the risk of HIV/AIDS in African Ameri- } \\
\text { can college students: an exploratory investigation of the efficacy of a peer educator } \\
\text { approach. Health Promot Pract. 2014;15(2):181-8. doi:10.1177/1524839913504757 }\end{array}$ & $\begin{array}{l}\text { szexuális ne- } \\
\text { velés }\end{array}$ & Észak-Amerika \\
\hline 147 & $\begin{array}{c}\text { McCrystal P, McAleavy G. Addressing health care in Northern Ireland through collabora- } \\
\text { tive peer education. Int J Health Promot Educ. 2014;38(3):76-85. } \\
\text { doi:https://doi.org/10.1080/14635240.2000.10806154 }\end{array}$ & $\begin{array}{l}\text { általános } \\
\text { egészség }\end{array}$ & Európa \\
\hline 148 & $\begin{array}{c}\text { Layzer C, Rosapep L, Barr S. A Peer Education Program: Delivering Highly Reliable Sexual } \\
\text { Health Promotion Messages in Schools. J Adolesc Health. 2014;54(3):S70-S77. } \\
\text { doi:10.1016/j.jadohealth.2013.12.023 }\end{array}$ & $\begin{array}{l}\text { szexuális ne- } \\
\text { velés }\end{array}$ & Észak-Amerika \\
\hline 149 & $\begin{array}{c}\text { Ayaz S, Acil D. Comparison of Peer Education and the Classic Training Method for School } \\
\text { Aged Children Regarding Smoking and its Dangers. J Pediatr Nurs. 2014;30(3):e3-e12. } \\
\text { doi:10.1016/j.pedn.2014.11.009 }\end{array}$ & $\begin{array}{l}\text { káros szenve- } \\
\text { dély }\end{array}$ & Ázsia \\
\hline 150 & $\begin{array}{c}\text { McKinney C, Bishop V, Cabrera K, et al. NuFit: nutrition and fitness CBPR program eva- } \\
\text { luation. J Prev Interv Community. 2014;42(2):112-24. } \\
\text { doi:10.1080/10852352.2014.881180 }\end{array}$ & táplálkozás & Észak-Amerika \\
\hline 151 & $\begin{array}{l}\text { Eskicioglu P, Halas J, Sénéchal M, et al. Peer Mentoring for Type } 2 \text { Diabetes Prevention } \\
\text { in First Nations Children. Pediatrics. 2014;133(6):e1624-31. doi:10.1542/peds.2013- } \\
2621\end{array}$ & táplálkozás & Észak-Amerika \\
\hline 152 & $\begin{array}{c}\text { Di Noia J, Orr L, Byrd-Bredbenner C. Residential Summer Camp Intervention Improves } \\
\text { Camp Food Environment. Am J Health Behav. 2014;38(4):631-640. } \\
\text { doi:10.5993/AJHB.38.4.17 }\end{array}$ & táplálkozás & Észak-Amerika \\
\hline 153 & $\begin{array}{c}\text { Morales A, Espada JP, Orgilés M, et al. The short-term impact of peers as co-facilitators } \\
\text { of an HIV prevention programme for adolescents: a cluster randomised controlled trial. } \\
\text { Eur J Contracept Reprod Health Care. 2014;19(5):379-391. } \\
\text { doi:10.3109/13625187.2014.919445 }\end{array}$ & $\begin{array}{c}\text { szexuális ne- } \\
\text { velés }\end{array}$ & Európa \\
\hline 154 & $\begin{array}{l}\text { McMahon S, Winter SC, Palmer JE, et al. A randomized controlled trial of a multi-dose } \\
\text { bystander intervention program using peer education theater. Health Educ Res. } \\
\text { 2015;30(4):554-568. doi:https://doi.org/10.1093/her/cyv022 }\end{array}$ & lelki egészség & Észak-Amerika \\
\hline 155 & $\begin{array}{l}\text { Davis R, Loescher } L \text {, Rogers J, et al. Evaluation of Project Students are Sun Safe (SASS): } \\
\text { A University Student-Delivered Skin Cancer Prevention Program for Schools. J Cancer } \\
\text { Educ. 2015;30(4):736-42. doi:10.1007/s13187-014-0742-7 }\end{array}$ & betegség & Észak-Amerika \\
\hline 156 & $\begin{array}{l}\text { Williams B, Hardy K, McKenna L. Near-Peer Teaching in Paramedic Education: Results } \\
\text { from } 2011 \text { to 2013. Medical Science Educator. 2015;25(2):149-156. }\end{array}$ & egyéb & Ausztrália \\
\hline 157 & $\begin{array}{l}\text { Menna T, Ali A, Worku A. Effects of peer education intervention on HIV/AIDS related se- } \\
\text { xual behaviors of secondary school students in Addis Ababa, Ethiopia: a quasi-experi- } \\
\text { mental study. Reprod Health. 2015;(12):84. doi:10.1186/s12978-015-0077-9 }\end{array}$ & $\begin{array}{l}\text { szexuális ne- } \\
\text { velés }\end{array}$ & Afrika \\
\hline 158 & $\begin{array}{l}\text { Beck S, Issleib M, Daubmann A, et al. Peer education for BLS-training in schools? Results } \\
\text { of a randomized-controlled, noninferiority trial. Resuscitation. 2015;(94):85-90. } \\
\text { doi:10.1016/j.resuscitation.2015.06.026. }\end{array}$ & $\begin{array}{l}\text { elsősegély, } \\
\text { baleset }\end{array}$ & Európa \\
\hline 159 & $\begin{array}{l}\text { Kovács DÁ, Mihály S, Rajczy K, et al. Gerundium: A comprehensive public educational } \\
\text { program on organ donation and transplantation and civil law in Hungary. Transplant } \\
\text { Proc. 2015;47(7):2186-8. doi:10.1016/j.transproceed.2015.07.028. }\end{array}$ & betegség & $\begin{array}{l}\text { Európa (Ma- } \\
\text { gyar- } \\
\text { ország) }\end{array}$ \\
\hline 160 & $\begin{array}{l}\text { Ross HM, Deraing JA, Rollins AL. Oklahoma's youth-driven tobacco policy campaigns: as- } \\
\text { sessment of impacts and lessons learned. Am J Prev Med. 2015;48(1 Suppl 1):S36-43. } \\
\text { doi:10.1016/j.amepre.2014.10.001 }\end{array}$ & $\begin{array}{l}\text { káros szenve- } \\
\text { dély }\end{array}$ & Észak-Amerika \\
\hline 161 & $\begin{array}{c}\text { Benni E, Sacco S, Bianchi L, et al. Evaluation outcomes of a sex education strategy in } \\
\text { high schools of Pavia (Italy). Glob Health Promot. 2016;23(2):15-29. } \\
\text { doi:10.1177/1757975914558309 }\end{array}$ & $\begin{array}{c}\text { szexuális ne- } \\
\text { velés }\end{array}$ & Európa \\
\hline 162 & $\begin{array}{l}\text { O'Reilly A, Barry J, Neary ML, et al. An evaluation of participation in a schools-based yo- } \\
\text { uth mental health peer education training programme. Advances In School Mental He- } \\
\text { alth Promotion, 2016;9(2):107-118. doi:doi.org/10.1080/1754730X.2016.1154794 }\end{array}$ & lelki egészség & Európa \\
\hline
\end{tabular}




\begin{tabular}{|c|c|c|c|}
\hline 163 & $\begin{array}{l}\text { Swartz S, Deutsch C, Moolman B, et al. Ensuring an optimal environment for peer edu- } \\
\text { cation in South African schools: Goals, systems, standards and policy options for ef- } \\
\text { fective learning. Afr J AIDS Res. 2016;15(4):359-366. } \\
\text { doi:10.2989/16085906.2016.1251474 }\end{array}$ & $\begin{array}{l}\text { szexuális ne- } \\
\text { velés }\end{array}$ & Afrika \\
\hline 164 & $\begin{array}{l}\text { Palladino BE, Nocentini A, Menesini E, et al. Evidence-based intervention against bully- } \\
\text { ing and cyberbullying: Evaluation of the NoTrap! program in two independent trials. } \\
\text { Aggress Behav. 2016;42(2):194-206. doi:10.1002/ab.21636. }\end{array}$ & lelki egészség & Európa \\
\hline 165 & $\begin{array}{l}\text { Sharif Ishak SI, Chin YS, Mohd Taib MN, et al. School-based intervention to prevent } \\
\text { overweight and disordered eating in secondary school Malaysian adolescents: A study } \\
\text { protocol. BMC Public Health. 2016;16(1):1101. doi:doi.org/10.1186/s12889-016-3773-7 }\end{array}$ & táplálkozás & Ázsia \\
\hline 166 & $\begin{array}{c}\text { Bühler A, Thrul J, Strüber E, et al. Cluster-randomized trial of a German leisure-based al- } \\
\text { cohol peer education measure. Health Promot Int. 2016;31(2):385-395. } \\
\text { doi:10.1093/heapro/dav007 }\end{array}$ & táplálkozás & Európa \\
\hline 167 & $\begin{array}{c}\text { de Menezes S, Premnath D. Near-peer education: a novel teaching program. Int J Med } \\
\text { Educ. 2016;30(7):160-7. doi:10.5116/ijme.5738.3c28. }\end{array}$ & $\begin{array}{l}\text { általános } \\
\text { egészség }\end{array}$ & Ausztrália \\
\hline 168 & $\begin{array}{l}\text { Devosa I, Kozinszky Z, Vanya M, et al. Szegedi egyetemi hallgatók ismeretei a megbíz- } \\
\text { ható fogamzásgátlásról és a szexuális úton terjedő betegségekről. Orv. Hetil. } \\
\text { 2016;157(14):539-546. doi:https://doi.org/10.1556/650.2015.30356 }\end{array}$ & $\begin{array}{l}\text { szexuális ne- } \\
\text { velés }\end{array}$ & $\begin{array}{l}\text { Európa (Ma- } \\
\text { gyar-ország) }\end{array}$ \\
\hline 169 & $\begin{array}{l}\text { Bogart LM, Elliott MN, Cowgill BO, et al. Two-year BMI outcomes from a school-based } \\
\text { Intervention for nutrition and exercise: A randomized trial. Pediatrics. } \\
\text { 2016;137(5):e20152493. doi:10.1542/peds.2015-2493 }\end{array}$ & táplálkozás & Észak-Amerika \\
\hline 170 & $\begin{array}{l}\text { Taggart T, Taboada A, Stein JA, et al. A cross-site analysis of the effects of a theater- } \\
\text { based intervention on adolescent awareness, attitudes, and knowledge about HIV. Prev } \\
\text { Sci. 2016;17(5):544-53. doi:10.1007/s11121-016-0645-4 }\end{array}$ & $\begin{array}{l}\text { szexuális ne- } \\
\text { velés }\end{array}$ & Észak-Amerika \\
\hline 171 & $\begin{array}{l}\text { Szombathelyi D., Horváth Z. Középiskolások táplálkozási szokásai. Új Diéta. } \\
\text { 2016/5;15(5):7-10. }\end{array}$ & táplálkozás & $\begin{array}{l}\text { Európa (Ma- } \\
\text { gyar-ország) }\end{array}$ \\
\hline 172 & $\begin{array}{c}\text { Vu L, Burnett-Zieman B, Banura C, et al. Increasing uptake of HIV, sexually transmitted } \\
\text { infection, and family planning services, and reducing HIV-related risk behaviors among } \\
\text { youth living with HIV in Uganda. J Adolesc Health. 2017;60(2):S22-S28. } \\
\text { doi:doi.org/10.1016/j.jadohealth.2016.09.007 }\end{array}$ & $\begin{array}{l}\text { szexuális ne- } \\
\text { velés }\end{array}$ & Afrika \\
\hline 173 & $\begin{array}{l}\text { Young VL, Cole A, Lecky DM, et al. A mixed-method evaluation of peer-education } \\
\text { workshops for school-aged children to teach about antibiotics, microbes and hygiene. J } \\
\text { Antimicrob Chemother. 2017;72(7):2119-2126. doi:10.1093/jac/dkx083 }\end{array}$ & higiénia & Európa \\
\hline 174 & Debreceni Orvostanhallgatók Egyesülete. http://doe.dote.hu/ & $\begin{array}{l}\text { általános } \\
\text { egészség }\end{array}$ & $\begin{array}{l}\text { Európa (Ma- } \\
\text { gyar-ország) }\end{array}$ \\
\hline 175 & $\begin{array}{l}\text { Szegedi Orvostanhallgatók Egyesülete. http://szeged.humsirc.hu/http://szeged.hum- } \\
\text { sirc.hu/oldalak/magyar/fejlec.php?id=egyesulet_kozhaszn }\end{array}$ & $\begin{array}{l}\text { általános } \\
\text { egészség }\end{array}$ & $\begin{array}{l}\text { Európa (Ma- } \\
\text { gyar-ország) }\end{array}$ \\
\hline 176 & $\begin{array}{c}\text { Budapesti Orvostanhallgatók Kortársoktató Alapítványa. http://www.ma- } \\
\text { daszsz.hu/oda/html/07102.html }\end{array}$ & $\begin{array}{l}\text { általános } \\
\text { egészség }\end{array}$ & $\begin{array}{l}\text { Európa (Ma- } \\
\text { gyar-ország) }\end{array}$ \\
\hline 177 & $\begin{array}{l}\text { Nemzeti Együttmúködési Alap - Ifjúsági Szolgáltatók Országos Szövetsége. Borsos László } \\
\text { Kortársoktatás-segítés, mint egészségnevelési módszer. } \\
\text { http://www.iszosz.org/downloads/NEA_Kortarsoktat\%C3\%A1s_segites.pdf }\end{array}$ & $\begin{array}{l}\text { szexuális ne- } \\
\text { velés }\end{array}$ & $\begin{array}{l}\text { Európa (Ma- } \\
\text { gyar-ország) }\end{array}$ \\
\hline 178 & Kompánia Alapítvány. www.kompania.hu & lelki egészség & $\begin{array}{l}\text { Európa (Ma- } \\
\text { gyar-ország) }\end{array}$ \\
\hline 179 & $\begin{array}{c}\begin{array}{c}\text { Debreceni Egyetem Mentálhigiénés és Esélyegyenlőségi Központ. http://www.lelki- } \\
\text { ero.unideb.hu/ }\end{array}\end{array}$ & lelki egészség & $\begin{array}{l}\text { Európa (Ma- } \\
\text { gyar-ország) }\end{array}$ \\
\hline 180 & ELTE Kortárs Segítő Csoport. http://kortars.elte.hu/ & lelki egészség & $\begin{array}{l}\text { Európa (Ma- } \\
\text { gyar-ország) }\end{array}$ \\
\hline 181 & Passz Kortárs Segítő Csoport. http://www.passsz.eoldal.hu/ & lelki egészség & $\begin{array}{l}\text { Európa (Ma- } \\
\text { gyar-ország) }\end{array}$ \\
\hline 182 & Kortárs Segítő Műhely Alapítvány. http://www.ksma.hu/ & lelki egészség & $\begin{array}{l}\text { Európa (Ma- } \\
\text { gyar- } \\
\text { ország) }\end{array}$ \\
\hline
\end{tabular}




\begin{tabular}{|c|c|c|c|}
\hline 183 & Kortársoktatók Pécsi Egyesülete. http://www.madaszsz.hu/oda/html/06004.html & lelki egészség & $\begin{array}{l}\text { Európa (Ma- } \\
\text { gyar-ország) }\end{array}$ \\
\hline 184 & Együttható Közösségépítő Egyesület. http://www.egyutthato.eu/ & lelki egészség & $\begin{array}{l}\text { Európa (Ma- } \\
\text { gyar-ország) }\end{array}$ \\
\hline 185 & Agóra Családsegítő Alapítvány. http://agora.non-profit.hu/ & lelki egészség & $\begin{array}{l}\text { Európa (Ma- } \\
\text { gyar-ország) }\end{array}$ \\
\hline 186 & $\begin{array}{c}\text { AGORA - LOGO Ifjúsági Szolgálat. Kortársképzés. http://www.agorasavaria.hu/progra- } \\
\text { mok/eloadas-tanc-kiallitas/kortars-kepzes }\end{array}$ & $\begin{array}{l}\text { káros szenve- } \\
\text { dély }\end{array}$ & $\begin{array}{l}\text { Európa (Ma- } \\
\text { gyar-ország) }\end{array}$ \\
\hline 187 & $\begin{array}{c}\text { Miskolci Önkormányzat és helyi iskolák. Kortársképzés. http://minap.hu/cikkek/legyen- } \\
\text { eszed-hogy-eszed-legyen-drogprevencios-kortarskepzes }\end{array}$ & $\begin{array}{l}\text { káros szenve- } \\
\text { dély }\end{array}$ & $\begin{array}{l}\text { Európa (Ma- } \\
\text { gyar-ország) }\end{array}$ \\
\hline 188 & Vasi Ifjúságért Egyesület. http://www.vasiifjusagert.hu/ & $\begin{array}{l}\text { káros szenve- } \\
\text { dély }\end{array}$ & $\begin{array}{l}\text { Európa (Ma- } \\
\text { gyar-ország) }\end{array}$ \\
\hline 189 & Szegedi Tini-telefon Lelkisegélyszolgálat Egyesület. http://www.tizentul.hu/ & $\begin{array}{l}\text { káros szenve- } \\
\text { dély }\end{array}$ & $\begin{array}{l}\text { Európa (Ma- } \\
\text { gyar-ország) }\end{array}$ \\
\hline 190 & Magyar Vöröskereszt Nógrád megyei Szervezete, Salgótarján. http://voroskereszt.hu/ & $\begin{array}{l}\text { káros szenve- } \\
\text { dély }\end{array}$ & $\begin{array}{l}\text { Európa (Ma- } \\
\text { gyar-ország) }\end{array}$ \\
\hline 191 & $\begin{array}{l}\text { LOGO Ifjúsági Szolgálat - Vas Megyei Ifjúsági Szakmai Módszertani Központ - helyi Kábí- } \\
\text { tószerügyi Egyeztető Fórum. http://www.vasvili.hu/kortars-klub/kortassegito-kepzes }\end{array}$ & $\begin{array}{l}\text { káros szenve- } \\
\text { dély }\end{array}$ & $\begin{array}{l}\text { Európa (Ma- } \\
\text { gyar-ország) }\end{array}$ \\
\hline 192 & $\begin{array}{l}\text { „Egészséged testben, lélekben”. http://www.tiszavasvari.hu/files/jobboszlop/KEF/Aktu- } \\
\text { alis/drogmegelozo_program.doc }\end{array}$ & $\begin{array}{l}\text { káros szenve- } \\
\text { dély }\end{array}$ & $\begin{array}{l}\text { Európa (Ma- } \\
\text { gyar-ország) }\end{array}$ \\
\hline 193 & Esély Csoport. ELTE BTK - ELTE PPK. http://kortars.elte.hu/ & egyéb & $\begin{array}{l}\text { Európa (Ma- } \\
\text { gyar-ország) }\end{array}$ \\
\hline 194 & Palotás Ifjúsági Vöröskereszt. http://www.palotas.hu/gylato/voroskereszt_main.html & betegség & $\begin{array}{l}\text { Európa (Ma- } \\
\text { gyar-ország) }\end{array}$ \\
\hline
\end{tabular}

